\title{
Factors controlling Li concentration and isotopic composition in formation waters and host rocks of Marcellus Shale, Appalachian Basin
}

\author{
Thai T. Phan ${ }^{1,2, *}$, Rosemary C. Capo ${ }^{1}$, Brian W. Stewart ${ }^{1}$, G. L. Macpherson ${ }^{3}$, Elisabeth L. \\ Rowan $^{4}$, Richard W. Hammack ${ }^{2}$ \\ ${ }^{1}$ Department of Geology and Planetary Science, University of Pittsburgh, Pittsburgh, PA, 15260, \\ USA \\ ${ }^{2}$ U.S. Department of Energy, National Energy Technology Laboratory, Pittsburgh, PA 15236, \\ USA \\ ${ }^{3}$ Department of Geology, University of Kansas, Lawrence, KS, 66045, USA \\ ${ }^{4}$ U.S. Geological Survey, Reston, VA, 20192, USA
}

*Corresponding author:

Thai T. Phan

Department of Geology and Planetary Science

University of Pittsburgh

4107 O’Hara St., 200SRCC, Pittsburgh, PA, 15260 USA

Phone: 412-728-5502

Email: thaiphan@pitt.edu OR thai.phan@netl.doe.gov

(C) 2015. This manuscript version is made available under the Elsevier user license http://www.elsevier.com/open-access/userlicense/1.0/ 


\section{Abstract}

In this study, water and whole rock samples from hydraulically fractured wells in the Marcellus Shale (Middle Devonian), and water from conventional wells producing from Upper Devonian sandstones were analyzed for lithium concentrations and isotope ratios $\left(\delta^{7} \mathrm{Li}\right)$. The distribution of lithium concentrations in different mineral groups was determined using sequential extraction. Structurally bound Li, predominantly in clays, accounted for 75-91 wt. \% of total $\mathrm{Li}$, whereas exchangeable sites and carbonate cement contain negligible $\mathrm{Li}(<3 \%)$. Up to $20 \%$ of the $\mathrm{Li}$ is present in the oxidizable fraction (organic matter and sulfides). The $\delta^{7} \mathrm{Li}$ values for whole rock shale in Greene Co., Pennsylvania, and Tioga Co., New York, ranged from -2.3 to $+4.3 \%$, similar to values reported for other shales in the literature. The $\delta^{7} \mathrm{Li}$ values in shale rocks with stratigraphic depth record progressive weathering of the source region; the most weathered and clay-rich strata with isotopically light Li are found closest to the top of the stratigraphic section. Diagenetic illite-smectite transition could also have partially affected the bulk Li content and isotope ratios of the Marcellus Shale.

In Greene Co., southwest Pennsylvania, the Upper Devonian sandstone formation waters have $\delta^{7} \mathrm{Li}$ values of $+14.6 \pm 1.2(2 \mathrm{SD}, \mathrm{n}=25)$, and are distinct from Marcellus Shale formation waters which have $\delta^{7} \mathrm{Li}$ of $+10.0 \pm 0.8(2 \mathrm{SD}, \mathrm{n}=12)$. These two formation waters also maintain distinctive ${ }^{87} \mathrm{Sr} /{ }^{86} \mathrm{Sr}$ ratios suggesting hydrologic separation between these units. Applying temperature-dependent illitilization model to Marcellus Shale, we found that Li concentration in clay minerals increased with Li concentration in pore fluid during diagenetic illite-smectite transition. Samples from north central PA show a much smaller range in both $\delta^{7} \mathrm{Li}$ and ${ }^{87} \mathrm{Sr} /{ }^{86} \mathrm{Sr}$ than in southwest Pennsylvania. Spatial variations in $\mathrm{Li}$ and $\delta^{7} \mathrm{Li}$ values show that Marcellus formation waters are not homogeneous across the Appalachian Basin. Marcellus formation waters in the northeastern Pennsylvania portion of the basin show a much smaller range in both 
$\delta^{7} \mathrm{Li}$ and ${ }^{87} \mathrm{Sr} /{ }^{86} \mathrm{Sr}$, suggesting long term, cross-formational fluid migration in this region. Assessing the impact of potential mixing of fresh water with deep formation water requires establishment of a geochemical and isotopic baseline in the shallow, fresh water aquifers, and site specific characterization of formation water, followed by long-term monitoring, particularly in regions of future shale gas development.

Keywords: Marcellus Shale, formation water, lithium isotopes, strontium isotopes, detrital clay, progressive weathering, geochemical tracer. 


\section{Introduction}

Lithium (Li) isotopes have been widely used as a tracer for Earth surface processes, including origin and evolution of basinal brines (Bottomley et al., 1999; Macpherson et al., 2014) and weathering of silicate rocks (Millot et al., 2010b; Misra and Froelich, 2012; Pogge von Strandmann et al., 2013). Lithium is a fluid-mobile element whose concentration and isotopic composition vary widely among geologic materials. The magnitude of $\mathrm{Li}$ isotope fractionation is found to be inversely related to the temperature during water-rock interactions (Millot et al., 2010a; Vigier et al., 2008). Clay formation produces Li isotope fractionation at both low and high temperatures, with the light isotope ${ }^{6} \mathrm{Li}$ preferentially incorporated into the structure of clay minerals leaving fluid enriched with the heavier isotope ${ }^{7} \mathrm{Li}$. Silicate weathering and secondary mineral formations are two main processes thought to induce $\mathrm{Li}$ isotope fractionation (Rudnick et al., 2004; Pogge von Strandmann et al., 2006; Vigier et al., 2009) in geologic materials.

Laboratory experiments on Li isotope fractionation, including adsorption (Pistiner and Henderson, 2003; Millot and Girard, 2007), interactions of sea water with basalts (Millot et al., 2010a), precipitation of carbonate minerals (Marriott et al., 2004), and illitization (Williams and Hervig, 2005) have demonstrated the same fractionation direction in which ${ }^{6} \mathrm{Li}$ is preferentially incorporated into secondary minerals, even though the fractionation factors vary for each particular process. Lithium with calcite and aragonite are about 3\%o and 11\%o isotopically lighter, respectively, than Li in the initial (growth) solution (Marriott et al., 2004). On the other hand, dissolution of primary minerals does not significantly fractionate Li isotopes (Burton and Vigier, 2012). To date, processes controlling Li isotope fractionation from water and shale interactions are poorly understood. Teng et al. (2004) investigated shale samples in different cores from four basins in Australia; the samples' ages ranged from Proterozoic to Triassic. Li 
concentrations and isotope ratios, reported as $\delta^{7} \mathrm{Li}$ relative to the LSVEC standard, ranged from 30 to $109 \mathrm{mg} / \mathrm{kg}$ and -3.1 to $+3.4 \%$, respectively. A similar range of $\delta^{7} \mathrm{Li}(-3.4$ to $+0.4 \%$ ) was reported for Paleozoic sedimentary rocks in Germany based on a more extensive data set (Romer and Meixner, 2014); however, these were primarily outcrop samples, which can be strongly affected by near-surface processes (e.g., Mosier, 1988). Lithium concentrations and isotope ratios of in situ basinal brines and Marcellus Shale core samples represent a stepping stone for understanding water-shale interactions.

In unconventional gas plays the reservoir rock is typically the same as the source rock. The Middle Devonian Marcellus Shale is an organic-rich, low permeability shale with a significant reservoir of gas that has been rapidly developed over the last decade. Previous studies have showed that the saline waters collected from Marcellus Shale gas wells are classified as Na$\mathrm{Ca}-\mathrm{Cl}$ type brine with median value of total dissolved solids (TDS) of 278,000 mg/L (Dresel and Rose, 2010; Rowan et al., 2015). Major cations and anions, strontium isotopes, and oxygen isotopes show that water produced from the Marcellus Shale is initially dominated by the fluid injected for hydraulic fracturing but shifts over time to the composition of the formation water (Chapman et al., 2012; Haluszczak et al., 2013; Capo et al., 2014; Rowan et al., 2015). Evaporation of sea water can explain the high TDS (Haluszczak et al., 2013; Rowan et al., 2015) but does not adequately explain the elevated Li concentrations in the Marcellus produced water (Macpherson et al., 2014). Diagenetic reactions with Li-bearing minerals in the shale could possibly account for anomalously high Li in Marcellus formation water (Macpherson et al., 2014). This study further investigates sources of Li by characterizing Li concentration and isotopic composition in both formation waters and rock samples of the Marcellus Shale. Sequential extraction experiments were conducted to determine the distribution of Li in shale 
minerals. We interpret the results in the context of rock-water interaction at temperatures estimated for maximum burial and at present day in the reservoir. Both $\mathrm{Li}$ and $\mathrm{Sr}$ isotopes are shown to be useful geochemical tracers of the formation waters on a local scale.

\section{Materials and methods}

\subsection{Sample description and geological setting}

Water samples were collected from oil and gas wells producing from Upper and Middle Devonian, and Silurian reservoirs. The well locations ranged from southwestern to north-central Pennsylvania, USA (Fig. 1). Water samples were collected from a total of three conventional gas wells from multiple units of Upper Devonian (UD-2, UD-5, UD-6) and five hydraulically fractured gas wells from the Middle Devonian Marcellus Shale (four horizontal wells: Well 7, 8, 9, 10; one vertical well: Well MW1). During hydraulic fracturing, fluid comprising fresh water, recycled produced water, chemical additives and sand (Soeder et al., 2014) is injected into the target formation under pressures high enough to create fractures along the length of the wellbore. As pressure is released, large amounts of the injected water return to the surface during the first few weeks; this is often termed "flowback water". In this paper we use the term "produced water" to describe all water returned to the surface, regardless of timing. The chemistry of the produced water changes rapidly and reaches a stable composition over a short period, after which the in situ brine dominates the composition of the produced water. Therefore, the term "formation water" discussed in this study implies the in situ water from the hydraulically fractured formation that dominates the composition of produced water at the later stages of gas production ( $>45$ days). Early produced water is likely a mixture of the injected water and formation water. 
The vertical Marcellus well (MW-1) was hydraulically fractured in June 2008 and had been in operation for more than five years by the time of our sampling. Thus, all water samples from this well are derived from the in situ formation water and are not influenced by the injected fluid. On the other hand, time series water samples from four horizontal wells in three counties (Greene, Washington, and Westmoreland) in southwestern Pennsylvania, USA, were collected from day 1 to as long as 813 days from the beginning of water return. Additional grab samples reported in this study include a) two samples from wells tapping the Silurian Lockport Dolomite and Newburgh Sandstone; b) two samples from Marcellus Shale wells in Tioga County, PA (approximately 850 and 1,060 days in production); and c) one sample from a gas well (approximately 1,100 days in production) tapping the Upper Devonian Burket Shale in Tioga County, PA, USA. All water samples were collected by personnel from the U.S. Geological Survey or the National Energy Technology Laboratory-Pittsburgh. The samples were filtered through a $0.45 \mu \mathrm{m}$ membrane and acidified on site to $\mathrm{pH}<2$ using ultra pure $\mathrm{HNO}_{3}(\mathrm{Optima}$ grade, Fisher Scientific), following standard procedures described by Kharaka and Hanor (2003).

Marcellus Shale was obtained from a well core in Greene County, southwestern Pennsylvania (PA site, circle symbol, Fig. 1) and from dry-drilled cuttings from a well in Tioga County, southern New York (NY site, square symbol, Fig. 1). Sample depths cover the entire Marcellus Shale including Oatka Creek, Cherry Valley, and Union Springs Members, as well as adjacent units interpreted to be the Tully Limestone, Onondaga Limestone, and Oriskany Sandstone. These rock samples were powdered and one split was fully digested, while a second split underwent sequential extraction following procedures described in Phan et al. (2015). The sequential extraction experiments were conducted to quantify the distribution of $\mathrm{Li}$ in the aqueous phase, in water-soluble minerals, on exchangeable sites on clays and organic matter, in 
weak acid-soluble components (e.g. carbonate minerals), in the oxidizable fraction (e.g. sulfides and organic matter), and in residual phases (e.g. silicate minerals).

The Marcellus Shale consists of gray shale and carbonaceous black shale (Wang and Carr, 2013). It is the basal unit of Hamilton Group, and was deposited during the Acadian orogeny (Lash and Engelder, 2011). The Marcellus Shale is rich in clay minerals such as illite and chlorite, and in siliceous minerals such as quartz and feldspar. Illite and quartz represent on average approximately 25 and 35\% of the total volume of rock, respectively (Wang and Carr, 2013). All samples from Marcellus Shale analyzed in this study contain carbonate minerals, and the calcareous shales contain up to $18 \%$ carbonate (Phan et al., 2015). Illite and quartz are present in all shale samples from the Tioga County, NY site, according to semi-quantitative x-ray diffraction data (Johnson and Graney, 2015). At least 80 thin volcanic ash beds have been identified in the Middle to Lower Devonian, including the Marcellus Shale. Among these beds, Tioga A-G K-bentonites occur widely across the Appalachian Basin, mostly in the Onondaga Limestone and in some parts at the base of the Marcellus Shale (Hosterman and Whitlow, 1983; Ver Straeten, 2004), possibly contributing to the total Li content of the Marcellus Shale.

\subsection{Analytical methods}

\subsubsection{Metal concentrations}

Concentrations of lithium and sodium in produced water samples were measured at the University of Pittsburgh by ICP-MS under standard mode and KED mode, respectively. Internal standards were used to correct for non-spectral interferences. Groundwater ESL-2 and natural water NIST1640a reference standards were repeatedly measured, giving accuracy better than $5 \%$. All laboratory steps were done gravimetrically to avoid errors due to differences in the density of water samples. Metal concentrations $(\mathrm{mg} / \mathrm{L})$ in saline waters accounted for the specific 
gravity of the sample under standard laboratory conditions. Whole rock shale samples were analyzed for $\mathrm{TiO}_{2}, \mathrm{Nb}$, La, and Sm by ICP-MS after digestion by sodium peroxide $\left(\mathrm{Na}_{2} \mathrm{O}_{2}\right)$ fusion at Activation Laboratories. The estimated accuracy is within 5\%, as assessed by measurements of multiple certified reference rock standards.

\subsubsection{Lithium isotopes}

In all samples, lithium was separated from the sample matrix prior to measuring isotopic ratios. The lithium separation procedure developed in this study was modified from Choi et al. (2013) and previous studies (Tomascak et al., 1999; James and Palmer, 2000; Jeffcoate et al., 2004; Magna et al., 2004; Millot et al., 2004; Macpherson et al., 2014), in order to completely separate lithium from the matrix of limestone, shale, and saline water. Choi et al. (2013) reported a simple method that effectively separated lithium isotopes in variety of geological samples by only one column separation. We tested this method and found incomplete separation of lithium in samples of produced water and shale. Two significant modifications were necessary to completely separate lithium from our sample matrices: (1) we use $2.0 \mathrm{~mL}$ of the resin instead of $1.8 \mathrm{~mL}$, and (2) the eluent is $1.50 \mathrm{~N} \mathrm{HNO}_{3}: 70 \% \mathrm{CH}_{3} \mathrm{OH}$ instead of $1.2 \mathrm{~N} \mathrm{HNO}_{3}: 80 \% \mathrm{CH}_{3} \mathrm{OH}$. The modified separation method took approximately 8 hours.

All reagents used in this study are ultrapure (Optima Grade, Fisher Scientific) and laboratory steps were conducted in a clean room with Class 100 work spaces to minimize sample contaminations and maintain low blank levels. PFA vials and other laboratory ware were acidwashed before use. Cation exchange resin (AG50W-X8, 200-400 mesh; analytical grade; BioRad, USA) was prewashed multiple times with ultrapure $6 \mathrm{~N} \mathrm{HCl}, 2 \% \mathrm{HNO}_{3}$, and $18.2 \mathrm{M} \Omega$ Millipore water. The prewashed resin was stored in 18.2 M $\Omega$ Millipore water prior to use. The lithium separation procedure was calibrated routinely, especially for a new resin product lot or 
newly prepared and standardized nitric acid solution to assure complete recovery of Li and separation from $\mathrm{Na}$.

Aliquots of produced water and digestate of rock samples were measured to obtain approximately $0.2-0.4 \mu \mathrm{g} \mathrm{Li}$. The samples were dried in PFA vials at $95^{\circ} \mathrm{C}$ then dissolved in 0.50 $\mathrm{mL} 1.0 \mathrm{~N} \mathrm{HNO}_{3}$ before being loaded onto Bio-rad Poly-Prep columns $(0.8 \times 4 \mathrm{~cm})$ containing pre-conditioned resin. The lithium separation process is shown as a flow chart in Figure 2. The purified lithium fraction was diluted in $2 \% \mathrm{HNO}_{3}$ to make up $100 \mu \mathrm{g} / \mathrm{L}$ of lithium for MC-ICPMS measurement. For every sample, intensities (counts/second) of ${ }^{7} \mathrm{Li}$ and ${ }^{23} \mathrm{Na}$ in separate aliquots of the purified lithium fraction, and in ion-exchange-column aliquots collected before and after the purified lithium fraction, were determined by ICP-MS to check for lithium column recovery, blank, and $\mathrm{Na} / \mathrm{Li}$ mass ratio in the purified $\mathrm{Li}$ fraction. The $\mathrm{Na} / \mathrm{Li}$ (by weight) in all samples reported in this study was less than 5, which Bryant et al. (2003) found to have insignificant effect on the lithium isotopic ratio, especially under hot plasma condition.

The two lithium isotopes, ${ }^{7} \mathrm{Li}$ and ${ }^{6} \mathrm{Li}$, were measured simultaneously on a Neptune Plus MC-ICP-MS using Faraday cups $\mathrm{H} 4$ and L4, respectively. The measured ${ }^{7} \mathrm{Li} /{ }^{6} \mathrm{Li}$ ratio was corrected for blank contribution, and then normalized to the NIST SRM 8545 (LSVEC) reference material (purchased in 2012) using the standard-sample bracketing method. The lithium isotope ratio is reported as $\delta^{7} \mathrm{Li}(\%)=\left({ }^{7} \mathrm{Li} /{ }^{6} \mathrm{Li}_{\text {sample }} /{ }^{7} \mathrm{Li} /{ }^{6} \mathrm{Li}_{\mathrm{LSVEC}}-1\right) * 1000 .{ }^{7} \mathrm{Li} /{ }^{6} \mathrm{Li} \mathrm{LSVEC}_{\mathrm{L}}$ is the average of the measured ${ }^{7} \mathrm{Li} /{ }^{6} \mathrm{Li}$ ratio in the SRM8545 (LSVEC) reference material measured before and after the unknown (sample).

For every analytical batch, the ${ }^{7} \mathrm{Li} /{ }^{6} \mathrm{Li}$ of IRMM-016 standard (Qi et al., 1997) was also measured. All samples were measured in duplicate or triplicate (non-consecutively and usually at least 6 hours apart). Most of the water samples collected from Marcellus Shale were duplicated 
as full laboratory-procedure replicates. Seawater (S9148, Gulf of Mexico), in-house saline water standards, and international certified reference rock standards including basalt (BCR-1, JB-3), granite (JG-2, G2), shale (SGR1-b), rhyolite (JR-2), and andesite (AGV-1) were measured to check the precision and accuracy of the complete laboratory procedure. Two or three powder replicates of the certified reference rock samples were digested using the method described in Phan et al. (2015), and the $\mathrm{Li}$ isotope ratios were measured using the procedure described above. In addition, two in-house saline water samples previously reported for $\delta^{7} \mathrm{Li}$ (Macpherson et al., 2014) using a different separation method (James and Palmer, 2000) were measured repeatedly over the duration of the project using our modified procedure to check accuracy and reproducibility. The measured $\delta^{7} \mathrm{Li}$ of the geological reference standards and saline waters are listed in Table 1 and shown graphically in Figure 3.

The Li recovery from the separation column in all samples was greater than $99 \%$. The column blank contributed less than $0.005 \%$ of total lithium loaded onto the column and was considered negligible. For isotope ratios, in-run precision determined from the standard error of 15 cycles (integration time $=8.389 \mathrm{~s}$ ) typically ranged from 0.04 to $0.07 \%$. Repeated measurements of $100 \mu \mathrm{g} / \mathrm{L} \mathrm{LSVEC} \mathrm{standard} \mathrm{using} \mathrm{a} \mathrm{Jet} \mathrm{cone} \mathrm{and} \mathrm{X} \mathrm{skimmer} \mathrm{gave} \mathrm{a} \mathrm{precision} \mathrm{of}$ $0.06 \%$ o (2SD, $n=14)$ suggesting that there was no systematic change in the lithium isotope ratios during analysis. The average $\delta^{7} \mathrm{Li}$ of IRMM-016 measured over the duration of the analyses was $+0.2 \pm 0.2(2 \mathrm{SD}, \mathrm{n}=22)$ which is within analytical uncertainty with previously published data: for example, $+0.1 \pm 0.4$ (Macpherson et al., 2014); +0.3 \pm 1.0 (Penniston-Dorland et al., 2010); -0.5 \pm 0.9 (Liu et al., 2010); $-0.1 \pm 0.2$ (Teng et al., 2004); and $+0.4 \pm 1.4$ (Qi et al., 1997). Full laboratory procedural duplicates of water samples gave excellent reproducibility $(2 \mathrm{SD}=0.3 \%$, on average). Repeated analysis of the same in-house saline water standards previously reported 
in Macpherson et al. (2014) yielded excellent agreement (sample AP-MD002 and WA-A25 in Table 1). Our measured values of a wide range of rock types (andesite, basalt, granite, rhyolite, and shale) were within good agreement with the reported values (Table 1). Therefore, the external precision of the analytical method for lithium isotopes in this study, as estimated from long-term measurements of reference standards, was better than $1 \%$ (average long-term $2 \sigma$ uncertainty of approximately $0.5 \%$ ).

\subsubsection{Strontium isotopes}

The ${ }^{87} \mathrm{Sr} /{ }^{86} \mathrm{Sr}$ values of the produced water samples were determined by MC-ICP-MS following the procedure of Wall et al. (2013). Strontium isotope data reduction was processed using an in-house Microsoft Excel VBA (Visual Basic for Applications) macro program, in which corrections for interferences and mass fractionation are applied. Analysis of selected

produced water samples as in-house standards for ${ }^{87} \mathrm{Sr} /{ }^{86} \mathrm{Sr}$ agree within $0.005 \%$ of the previously reported values.

\section{Results}

\subsection{Sequential extractions and whole rock dissolution}

Lithium concentrations in whole rock samples of Marcellus Shale range from 36 to 48 $\mathrm{mg} / \mathrm{kg}$ and 19 to $85 \mathrm{mg} / \mathrm{kg}$ in PA and NY sites, respectively (Table 2). Concentrations in shales are generally higher than those in limestones or sandstones. The $\delta^{7} \mathrm{Li}$ values in Marcellus Shale range from -2.3 to $+4.3 \%$, similar to ranges reported for shales from other basins (Romer and Meixner, 2014; Teng et al., 2004), and the $\delta^{7} \mathrm{Li}$ values display positive correlations with sample depths in both locations. Onondaga Limestone samples from the NY site have $\delta^{7} \mathrm{Li}$ values from +13.3 to $+15.0 \%$, which are within the reported range ( +6 to $>+25 \%$ ) for limestones (Vigier et 
al., 2007; Misra and Froelich, 2012). However, samples of the Onondaga Limestone from the PA site have a distinctly lower $\delta^{7} \mathrm{Li}(+4.7 \%)$ and will be discussed below.

Results from the sequential extraction experiments for both sites show that $\mathrm{Li}$ is primarily associated with silicate minerals. Structurally bound $\mathrm{Li}$, such as in silicate minerals, accounted for $75-91 \%$ by weight of the total $\mathrm{Li}$, whereas exchangeable $\mathrm{Li}$ is less than $2 \%$ of total $\mathrm{Li}$ in the whole rock. Lithium in carbonate lenses within the Marcellus Shale and in limestone samples is less than $1 \mathrm{mg} / \mathrm{kg}$, which is in agreement with low Li reported for sedimentary carbonate (Millot et al., 2010b; Pogge von Strandmann et al., 2013).

The carbonate minerals extracted from our shale samples represented less than $10 \mathrm{wt} . \%$ of the sample (Phan et al., 2015), and low Li content $(<1 \mathrm{mg} / \mathrm{kg}$; $<2 \%$ total Li) was found in carbonate cement. This suggests that authigenic carbonate might, in part, dilute Li content in bulk shale rocks but have a negligible influence on isotopic composition. A sample from the Tully Limestone from the NY site contained 52.4\% carbonate minerals (Phan et al., 2015) but only $1.8 \%$ of the total $\mathrm{Li}$ in the whole-rock sample was extracted in the carbonate fraction. The whole rock $\delta^{7} \mathrm{Li}(-0.9 \%)$ is in the range previously reported for clays $(-1.5$ to $+5.0 \%$; Chan et al., 2006) and clay-rich shales (Table 2). Likewise, samples G7 and G8 from the Onondaga Limestone at the PA site contain 54 and 80 wt. \% carbonate, respectively (Phan et al., 2015). Only $4 \%$ and $6 \%$ of total $\mathrm{Li}$ was extracted in this fraction and the remaining $93 \%$ and $91 \%$ was structurally bound in residual minerals. Samples G7 and G8 exhibit higher $\delta^{7} \mathrm{Li}$ values $(+13.3 \%$ and $+15.0 \%$, respectively) than the limestone samples from the NY site. K-bentonite with high $\delta^{7} \mathrm{Li}$ values ( +5 to $+32 \%$; Williams et al., 2013) might also contribute to the high $\delta^{7} \mathrm{Li}$ values in the PA site Onondaga Limestone samples. 
The second largest reservoir of $\mathrm{Li}(0.5-9.6 \mathrm{mg} / \mathrm{kg}$, up to $20 \%$ of total $\mathrm{Li}$ in whole rock) is in the oxidizable fraction composed of organic matter and/or sulfide minerals; together they are the most dominant reduced phases in the Marcellus Shale.

\subsection{Produced waters}

$\mathrm{Li}, \mathrm{Na}$, and $\delta^{7} \mathrm{Li}$ data are presented in Table 3. Li concentrations in produced waters from Appalachian Basin reported in this study vary widely between geologic sections. Li in Upper Devonian produced water ranges from 18 to $30 \mathrm{mg} / \mathrm{L}$, whereas greater and geographicallyvariable concentrations $(18-233 \mathrm{mg} / \mathrm{L})$ of $\mathrm{Li}$ are found in the Middle Devonian produced water of the Marcellus Shale. In southwestern PA, Li concentrations in a time-series of samples increase over the first 45 days and reach the greatest average value of about $99 \mathrm{mg} / \mathrm{L}$ after 813 days of continuous production, and then remain constant (Table 3). Concentrations of Li in samples from the older vertical well range from 75 to $93 \mathrm{mg} / \mathrm{L}$, which is similar to the concentration in the formation water from horizontally-drilled Marcellus Shale wells in this area (average of $83 \mathrm{mg} / \mathrm{L}$ ). In north-central PA, elevated concentrations of Li (169-282 mg/L; Rowan et al., 2015) are in similar range to formation waters from Gulf Coast Sedimentary Basin, in which the greatest Li content is reported (322 mg/L; Macpherson et al., 2014) and are similar to the few high-Li formation waters in the Lower Devonian of southwestern PA (315 mg/L; Dresel and Rose, 2010; Macpherson, 2015). One brine sample from Burket Shale (sample ST-46, Table 3), at the base of the Upper Devonian formations, contains much higher Li (103 mg/L) than any other brines from Upper Devonian sandstones (18 -30 mg/L). On the other hand, formation waters of Lockport Dolomite (Upper Silurian) and Newburg Sandstone (Middle Silurian) from 
deeper reservoirs of Appalachian Basin contain Li concentrations of $21 \mathrm{mg} / \mathrm{L}$ and $154 \mathrm{mg} / \mathrm{L}$, respectively.

The $\delta^{7} \mathrm{Li}$ values of Marcellus formation waters vary spatially within the Appalachian Basin. In Greene County, PA, $\delta^{7} \mathrm{Li}$ values range from +9.2 to $+10.4 \%$ o $(+10.0 \pm 0.8(2 \mathrm{SD}), \mathrm{n}=$ 12) whereas they are $+14.3 \%$ and $+15.0 \%$ in two samples from Tioga County, PA. Upper Devonian formation water from multiple units, about $1000 \mathrm{~m}$ above the Middle Devonian formation water in the same location in Greene County, has $\delta^{7} \mathrm{Li}(+14.6 \pm 1.2(2 \mathrm{SD}), \mathrm{n}=25)$ that is easily distinguishable from the Marcellus Shale produced water. Nonetheless, $\delta^{7} \mathrm{Li}$ values of all brines of Appalachian Basin reported in this study are lower than $\delta^{7} \mathrm{Li}$ of both Cenozoic seawater $\left(\delta^{7} \mathrm{Li}=+22 \%\right.$ ) and modern seawater $\left(\delta^{7} \mathrm{Li}=+31 \%\right.$ ) $($ Misra and Froelich, 2012). Both Li concentrations and $\delta^{7} \mathrm{Li}$ values in produced waters from southwestern PA and north-central PA display positive correlations with TDS (Fig. 4).

Strontium isotope ratios of samples analyzed in this study and compiled from published data are reported in Table 4. In contrast with the $\delta^{7} \mathrm{Li}$ values, ${ }^{87} \mathrm{Sr} /{ }^{86} \mathrm{Sr}$ ratios in Middle Devonian formation water varies in a narrow range (0.70998-0.71173) across the basin and are lower than Upper Devonian formation waters (0.71977-0.72096). The ${ }^{87} \mathrm{Sr} /{ }^{86} \mathrm{Sr}$ ratios of two Silurian samples fall within the range of the Middle Devonian formation waters.

\subsection{Temporal trends in Li and $\delta$ Li in hydraulically fractured Marcellus shale gas wells}

Similar to previous observations based on chemical data (Hayes, 2009; Haluszczak et al., 2013) and multiple isotope systems including strontium (Capo et al., 2014; Stewart et al., 2015) and oxygen (Rowan et al., 2015), both lithium concentration and $\delta^{7} \mathrm{Li}$ in time-series produced waters from Marcellus Shale in southwestern PA increased over time in the first 45 days from the beginning of water return to well heads and remained constant over the 813 day duration of 
sampling (Figs. 5a and b). General increases in Li/Na over time (Fig. 5c) suggest that halite dissolution by the injected water (Blauch et al., 2009) is not likely a source of dissolved solids.

Even though mixing of the injected fluid with formation water is commonly accepted as the main process explaining the early chemical evolution of Marcellus produced water (Capo et al., 2014; Haluszczak et al., 2013; Stewart et al., 2015; Warner et al., 2014), water-rock interaction of the injected water with shale rocks, especially the water soluble and exchangeable components of shale rocks, should occur to some degree and could partially account for $\mathrm{Li}$ in produced water. Our calculation shows that dissolution of half of the total carbonate minerals (highest value of $\delta^{7} \mathrm{Li}$ was $+15.0 \%$ in limestone samples in this study; $\mathrm{Li}=1 \mathrm{mg} / \mathrm{kg}$, Table 2) in the Marcellus Shale would increase $\mathrm{Li}$ concentration and $\delta^{7} \mathrm{Li}$ in produced water by only $1 \mathrm{mg} / \mathrm{L}$ and $0.3 \%$, respectively, and thus does not explain the rapid and large increase in both $\mathrm{Li}$ and $\delta^{7} \mathrm{Li}$ in produced waters. Therefore, the contribution of $\mathrm{Li}$ from the dissolution of shale carbonate cement is negligible. Also, it has been suggested that desorption of Li from clay minerals due to interaction with injected fluid explains high Li in Marcellus produced water (Warner et al., 2014). Despite the large cation exchange capacity of Marcellus Shale (Staub, 2014), results from sequential extraction of Marcellus shale rocks show that lithium extracted from exchange sites is less than $2 \%$ of total $\mathrm{Li}$ in bulk shale, and so exchange-site-held Li cannot account for the elevated and isotopically heavier Li measured in the formation water.

Our results suggest that lithium concentrations and isotope ratios in early ( $<45$ days) Marcellus Shale produced water is minimally altered by interactions of the injected fluid with shale rocks and is primarily controlled by mixing of the injected fluid with in situ formation water. The low initial $\delta^{7} \mathrm{Li}$ values could be due to $\mathrm{Li}$ in proprietary chemicals added to the injected fluid or to dissolution of wellbore cement containing Li additives (e.g., Gu and 
Beaudoin, 1997; Deng et al., 2014) in the early $\mathrm{HCl}$ stage of hydraulic fracturing. Therefore, only late stage ( $>45$ days) water samples are used in the discussion of deep formation waters.

\section{Discussion}

\subsection{Controls of Li content and isotopic composition in shale rocks of Marcellus Shale}

4.1.1. Li isotopic evidence of continental weathering of detrital sediment

Lithium content and its isotopic composition in the Marcellus Shale, like any other sedimentary rock, are generally controlled by the detrital sediment sources, alteration during transport (Dellinger et al., 2014), and post depositional processes (Misra and Froelich, 2012; Qiu et al., 2011; Teng et al., 2007). Sequential extraction analysis indicates that $\mathrm{Li}$ is predominantly (75-91\%) structurally bound in silicate minerals (e.g., clays and feldspar) which dominate the residual fraction. As shown in Figure 6, Li concentrations in shales from drill core in the PA site do not vary systematically with depth. However, there is a significant decrease in $\mathrm{Li}$ concentration in shales in NY site with sample depth (Fig. 6a). When the Li concentration is normalized to $\mathrm{Al}_{2} \mathrm{O}_{3}$, shale samples in both study sites display strong positive correlations with depth (Fig. 6c and d), which is similar to an Al vs. depth profile of another drill core in the same county as the PA site (Lash and Blood, 2014). This suggests that source differences in these two locations probably control the inputs of detrital sediments, which in turn significantly control Li concentration and isotopic compositions of whole rock shales. During continental weathering, preferential incorporation of ${ }^{6} \mathrm{Li}$ into clays (Pistiner and Henderson, 2003; Rudnick et al., 2004; Tang et al., 2007; Liu et al., 2015) results in higher total Li content and isotopically lighter Li in clay-rich sediment, while clay-poor sediment, such as sand and silt, has less total Li and higher $\delta^{7} \mathrm{Li}$ (Figs. 6e and f). This suggests that, in both study sites, the sedimentary source material for the top of the Marcellus Shale was more progressively weathered and enriched with isotopically 
light Li toward the top of the Marcellus Shale compared to the basal section during deposition of the shale.

In order to further investigate this hypothesis, we examined the relationships of Li with other refractory elements including $\mathrm{Al}_{2} \mathrm{O}_{3}, \mathrm{TiO}_{2}$, and $\mathrm{Nb}$, which tend to be conserved during weathering and transport processes (Kurtz et al., 2000; Dellinger et al., 2014).

The relationships of Li to immobile elements are different at the two study locations (Figs. 7a, b, and c). There are generally positive correlations of $\mathrm{Li}$ with $\mathrm{Al}_{2} \mathrm{O}_{3}, \mathrm{TiO}_{2}$, and $\mathrm{Nb}$ at the NY site where concentrations of these elements vary widely. However, at the PA site, there is no correlation of $\mathrm{Li}$ with these immobile elements, implying that terrigenous input in the southwest portion of the study area was different than that in the northeast of the study area. In addition, $\mathrm{Al}_{2} \mathrm{O}_{3}, \mathrm{TiO}_{2}$, and $\mathrm{Nb}$ at $\mathrm{PA}$ site fall within a narrow range, while shales in the $\mathrm{NY}$ site display a wider range and extend to higher values. Thus, continental weathering may have been more intense and may have eroded more deeply at the NY site during Marcellus Shale deposition compared with the site in PA; this is consistent with the relative rise in sea level and greater clastic sedimentary input in the eastern side of the basin compared with the western side (Kohl et al., 2014).

Different Li abundances in the upper continental crust (UCC) have been estimated (e.g. 20 mg/kg, Taylor and McClennan, 1985; $24 \pm 5$ mg/kg, Rudnick and Gao, 2003; $35 \pm 10$ mg/kg, Teng et al., 2004; and $30.5 \pm 3.6 \mathrm{mg} / \mathrm{kg}$, Sauzéat et al., 2015). This study uses the value from Rudnick and Gao (2003) for discussion. Compared to UCC, eight out of nine shale samples analyzed in both sites have greater $\mathrm{Li}$ contents and all have greater $\mathrm{Li} / \mathrm{Al}_{2} \mathrm{O}_{3}, \mathrm{Li} / \mathrm{TiO}$, and $\mathrm{Li} / \mathrm{Nb}$ ratios than those in UCC. The shales reported in this study differ somewhat in Li content from estimations for average shales. For example, Ketris and Yudovich (2009) calculated median Li 
content for all black shales (31 ppm), and for carbonate shales (24 ppm), chert shales (19 ppm), and terrigenous and volcaniclastic shales (44 ppm). Most of the shales analyzed in this study are higher than these and other median values reported for Li in shales except for an average value (71 ppm; n=539) for shales and clays reported in Holland (1984) and one sample of oil shale analyzed in this study (134 ppm; Table 1). This indicates that Li was either controlled by weathering of the UCC, enriched during transport and deposition, affected by post-depositional processes such as illite-smectite transition, or was additionally influenced by other sources.

\subsubsection{Potential contribution of volcanic ash}

One other potential source of detrital sediments containing high concentrations of Li is volcanic ash. Its chemically weathered product, K-bentonite, has been observed in many locations in the Lower to Middle Devonian of the Appalachian Basin (Ver Straeten, 2004). The Tioga ash and numerous additional ash layers have been observed in outcrops and cores at the base of Marcellus Shale as well as in the upper Onondaga Formation (Hosterman and Whitlow, 1983; Parrish, 2013; Ver Straeten, 2004). It has been documented that silicate melt inclusions from rhyolite tuffs can be extremely enriched in Li. Tuffs from Spor Mountain, Utah have the highest Li content yet recorded, with a median concentration of 3,750 mg/kg (Hofstra et al., 2013). The Lower-Middle Devonian ash beds in the Appalachian Basin would need to contain $\sim 350 \mathrm{ppm} \mathrm{Li}$ in to yield the Li concentrations in the formation water and rock determined in this study. Li-rich rhyolite or rhyolite ash sourced from explosive volcanism during the Acadian orogeny (Ver Straeten, 2004) and weathering-derived clays may plausibly explain the high Li in Marcellus Shale relative to the upper continental crust (UCC).

Continentally derived sediments are generally enriched in light rare earth elements (LREE, with higher La/Sm) and isotopically light Li, whereas volcanic ash-dominated sediment 
has lower $\mathrm{La} / \mathrm{Sm}$ and higher $\delta^{7} \mathrm{Li}$. In addition, ash-rich sediment has relatively higher $\mathrm{TiO}_{2} / \mathrm{Al}_{2} \mathrm{O}_{3}$ because volcanic ash contains a high concentration of Ti (Chan et al., 2006). To determine the potential contribution of volcanic components to the Marcellus Shale, $\delta^{7} \mathrm{Li}$ vs. $\mathrm{La} / \mathrm{Sm}$ and $\mathrm{TiO}_{2} / \mathrm{Al}_{2} \mathrm{O}_{3}$ were plotted for shale samples from both sites, and for the UCC for comparison. As shown in Figures 7d and e, the $\mathrm{La} / \mathrm{Sm}$ and $\mathrm{TiO}_{2} / \mathrm{Al}_{2} \mathrm{O}_{3}$ ratios of all the shales studied are similar to those of the UCC and volcanic rocks (andesite, rhyodacite, dacite; Blatter and Carmichael, 1998; Bryant et al., 2006) indicating that analyzed shales may contain volcanogenic components. Moreover, whole shale $\delta^{7} \mathrm{Li}$ values at the base of Marcellus Shale in the Union Springs member are greater than the top (Fig. 6e and $f$ ) and in similar range of basaltic lavas ( +3 to $+5 \%$; Ryan and Kyle, 2004). In addition, a wide and positive range (+5 to $+32 \%$ ) was reported for clay fractions of K-bentonite from the central Baltic Basin (Williams et al., 2013) and K-bentonite was also observed in the Union Springs member strata at the base of Marcellus Shale (Ver Straeten, 2004). These lines of evidence suggest that Li concentration and isotopic composition in the Union Springs member at the base of Marcellus Shale could be partially affected by volcanogenic components. However, this is not the case for the clay rich shales with lower $\delta^{7} \mathrm{Li}$ values found at the top strata of Marcellus Shale which was more progressively weathered. Overall, the negative $\delta^{7} \mathrm{Li}$ trends (Figs. 6e and f) more likely reflect changes in weathering intensity during the deposition of the shale.

\subsubsection{Diagenesis of Marcellus Shale}

Calcium carbonate cements were observed widely in Marcellus Shale (Lash and Blood, 2014; Wang and Carr, 2012). It has been suggested that Li, like other alkali metals, is incorporated into interstitial positions during precipitation of calcium carbonate (Okumura and Kitano, 1986). Sequential extraction data show that less than $2 \%$ of total $\mathrm{Li}$ is found in carbonate 
cement; hence, authigenic carbonate minerals potentially dilute the Li concentration in whole shales but do not affect isotopic compositions. We also found negligible amounts of exchangeable Li compared to structural $\mathrm{Li}(\mathbf{F i g} .8 \mathrm{c})$. This is consistent with poor exchange affinity of Li and its propensity to be replaced by any competing cations in the fluid (Starkey, 1982).

Some of the variation in the $\delta^{7} \mathrm{Li}$ of the Marcellus Shale with depth could also be due to post-depositional processes. Assuming that $\mathrm{Al}_{2} \mathrm{O}_{3} / \mathrm{SiO}_{2}$ reflects the clay content (Teng et al., 2004), shales samples reported in this study show a fairly positive correlation of Li concentration with clay content (Fig. 8a). Results of sequential extraction experiments show that Li structurally bound to silicate minerals is the main component of $\mathrm{Li}$ in the Marcellus Shale. In addition, we found that there were negative correlations of both bulk Li content $(19-85 \mathrm{mg} / \mathrm{kg}$; Fig. 8b; $\mathrm{R}^{2}=0.80$ ) and structurally bound $\mathrm{Li}$ (not shown; $\mathrm{R}^{2}=0.76$ ) with $\delta^{7} \mathrm{Li}(-2.3$ to $+4.3 \%$ ) for samples at both sites. The same trend is observed when $\mathrm{Li}$ is normalized to $\mathrm{Nb}\left(\delta^{7} \mathrm{Li}\right.$ vs. $\mathrm{Li} / \mathrm{Nb} ; \mathrm{R}^{2}=0.71$; Fig. 7f). These negative correlations could reflect the incorporation of light ${ }^{6} \mathrm{Li}$ isotope into octahedral sites of clay minerals, according to experimental studies on lithium isotopic fractionation during clay formation (Decarreau et al., 2012; Vigier et al., 2009). A previous study (Hosterman and Whitlow, 1983) found that rocks of the Marcellus Shale contain an average of $50 \%$ clay minerals, of which illite and smectite-illite mixed layers contribute up to $85 \%$. Automated quantitative mineralogy (QEMSCAN) analysis of Marcellus Shale core sample revealed that illite appeared as thin flakes and filament pore-filling authigenic clay (Laughrey et al., 2011; slide 32). Assuming that shale samples from our study contain $30 \%$ illite, the median value reported for Marcellus Shale (Wang and Carr, 2012), Li concentration in illite in the PA and NY sites could be as much as 120 and $244 \mathrm{mg} / \mathrm{kg}$, respectively (based on maximum 
concentration of structurally bound Li determined in this study). These values are similar to the range of Li concentration in illite (>100 mg/kg; Williams et al., 2013) and in mixed clay minerals ( $<300 \mathrm{mg} / \mathrm{kg}$; Tardy et al., 1972). Results to date, then, suggest that Li concentration and isotopic composition in the Marcellus Shale were strongly controlled by clay minerals, which were primarily sourced from detrital input of progressively weathered sediments and could be additionally influenced by illite-smectite transition during diagenesis.

The second largest reservoir of $\mathrm{Li}$ in the Marcellus Shale was found in the oxidizable fraction, generally $11-20 \%$ of the total. This fraction displayed no correlation with bulk S, Fe, or TOC. This extraction was designed to measure Li associated with organic matter and sulfide minerals, the most dominant reduced phases in the Marcellus Shale. Pores hosted within organic matter were observed in Marcellus Shale, the largest of which can reach slightly more than $1 \mu \mathrm{m}$ in diameter (Milliken et al., 2013). Previous studies showed that numerous euhedral pyrite crystals and pyrite framboids are commonly observed in the Marcellus Shale (Kohl et al., 2014;

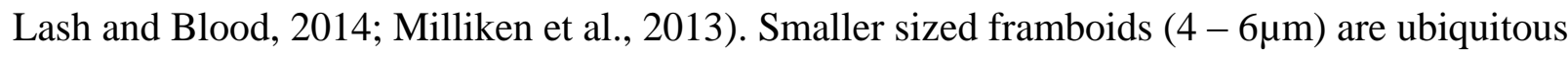
at the base of the Marcellus in the Union Springs Member, while larger $(>10 \mu \mathrm{m})$ framboids and euhedral pyrite crystals occur at the top of the Marcellus (Oatka Creek Member; Kohl et al., 2014). Whereas no information regarding concentration of $\mathrm{Li}$ in sulfide minerals has been reported, organic matter in Cambrian Alum shale, a hydrocarbon source rock, contributed more than $50 \%$ of total $\mathrm{Li}$ in shale (Williams et al., 2013). Additional work is needed to quantify the relative distribution and the mechanism of incorporation of $\mathrm{Li}$ in the oxidizable fraction of Marcellus Shale which could help answer important questions related to deposition and postdepositional fluid flow in the Marcellus Shale.

\subsubsection{Grain-size effects}


Previous studies showed that $\delta^{7} \mathrm{Li}$ values in modern river sediments (Dellinger et al., 2014) and desert loesses (Sauzéat et al., 2015) were controlled by mixing between minerals of different grain size fractions. In this section, we used $\mathrm{Al}_{2} \mathrm{O}_{3} / \mathrm{SiO}_{2}$ (Dellinger et al., 2014) and $\mathrm{Fe}_{2} \mathrm{O}_{3} / \mathrm{SiO}_{2}$ (Sauzéat et al., 2015) as grain-size proxies to determine whether grain-size effects could explain the negative trend of $\delta^{7} \mathrm{Li}$ vs. $\mathrm{Li} / \mathrm{Nb}$ (Fig. 7f). A plot (not shown) of $\mathrm{Al}_{2} \mathrm{O}_{3} / \mathrm{SiO}_{2}$ vs. $\mathrm{Fe}_{2} \mathrm{O}_{3} / \mathrm{SiO}_{2}$ for shale samples analyzed in this study and literature (Werne et al., 2002) display no correlation. The lack of correlation is expected because the siliciclastic sediment of the Marcellus Shale was controlled by multiple biogeochemical processes during deposition and diagenesis. For example, independent changes in silica flux (e.g., biogenic silica) with fluvial supply (Werne et al., 2002) altered $\mathrm{Al}_{2} \mathrm{O}_{3} / \mathrm{SiO}_{2}$ ratios which might not necessarily coincide with varying degrees of pyritization due to changes in redox conditions (Lash and Blood, 2014). In other words, these processes might not occur concurrently. Moreover, shales analyzed in this study encompassed the entire Marcellus Shale ( 25m thick for PA site and $\sim 50 \mathrm{~m}$ thick for NY site) which was deposited in multiple sequences with contribution of step-wise increased fluxes of detrital sediments (e.g. Kohl et al., 2014; Lash and Blood, 2014).

Therefore, these grain-size proxies cannot be reliably used to evaluate grain-size effects on the clastic sediment of Marcellus Shale. Although we cannot completely rule out the contribution of grain-size effects, the negative trend of $\delta^{7} \mathrm{Li}$ vs. $\mathrm{Li} / \mathrm{Nb}$ probably does not simply result from mixing of a fine grained end member, concentrated with clay minerals (high $\mathrm{Li} / \mathrm{Nb}-$ low $\delta^{7} \mathrm{Li}$ ) and a coarse grained end member, concentrated with silica-rich volcanogenic minerals (low Li/Nb - high $\delta^{7} \mathrm{Li}$ ). Therefore, the trends (Fig. 6; Fig. 7f) more likely reflect upward increase in weathering intensities from the lowest strata of Union Springs through the top section of Marcellus Shale. 


\subsection{Sources of elevated Li in Marcellus Shale formation water}

The divergence in both $\mathrm{Li}$ concentrations and $\delta^{7} \mathrm{Li}$ values suggests that Marcellus formation waters in the two study locations are not homogeneous. Positive correlations of Li vs. TDS $\left(\mathrm{R}^{2}=0.90\right)$, similar with trends observed for other cations (Rowan et al., 2015), and $\delta^{7} \mathrm{Li}$ vs. TDS ( $\mathrm{R}^{2}=0.84$; Fig. 4 ) suggest that the chemistry of formation water from the two study locations was likely controlled by a similar mechanism. The evaporation of seawater past the onset of halite precipitation, subsequently altered by diagenetic processes, and mixed with a more dilute fluid (Dresel and Rose, 2010; Rowan et al., 2015) adequately explains the TDS of Marcellus formation water. We use the same plot $(\mathrm{Li} / \mathrm{Cl}$ vs. $\mathrm{Br} / \mathrm{Cl})$ presented in Bagheri et al. (2014) for formation water in this study because this plot clearly shows $\mathrm{Li} / \mathrm{Cl}$ ratio relative to seawater evaporation trend. As shown in Figure 9, formation water from the Upper and Middle Devonian and from the Silurian units of the Appalachian Basin fall in the same range of $\mathrm{Li} / \mathrm{Cl}$ and $\mathrm{Br} / \mathrm{Cl}$ as formation waters of evaporated seawater origin (solid-line box). The fluid chemistry is distinct from brines originating from halite dissolution (dashed-dotted line box; Bagheri et al., 2014 and references therein). The $\mathrm{Li} / \mathrm{Cl}$ ratios of Marcellus formation waters (maximum of 0.01) are up to two orders of magnitude greater than the $\mathrm{Li} / \mathrm{Cl}$ ratios reported in highly evaporated seawater (McCaffrey et al., 1987), and they are also higher than those of formation waters from Upper Devonian and underlying Silurian strata (Warner et al., 2014; Rowan et al., 2015). Therefore, seawater evaporation alone cannot explain the elevated Li levels in Marcellus formation waters.

Some of the samples from Lower Silurian reservoirs (Warner et al., 2014) display Li concentrations and $\delta^{7} \mathrm{Li}$ values similar to formation water in Greene Co., PA. We show, however, that upward fluid migration from the Silurian is unlikely for two reasons. First, the 
Marcellus Shale is presently over-pressured (Aydin and Engelder, 2014), making it unlikely that brine would migrate into the formation. Secondly, results from previous studies using ${ }^{228} \mathrm{Ra} /{ }^{226} \mathrm{Ra}$ (Rowan et al., 2015) support the interpretation that in situ formation water is trapped within the Marcellus Shale whereas ${ }^{87} \mathrm{Sr} /{ }^{86} \mathrm{Sr}$ data suggest that the formation water could be have been water trapped within the shale or adjacent formations (Stewart et al., 2015). This study shows that elevated $\mathrm{Li}$ in Marcellus formation water is likely resulted from long-term alteration of volcanogenic rocks, primarily rhyolites, which in part control Li concentrations in whole rock shales during authigenic illite-smectite transition as discussed in Section 4.1.3.

Lithium concentrations in formation water in north-central PA are higher than in formation waters in southwestern PA. A similar relationship has been noted in the shale samples from the NY site (less than $150 \mathrm{~km}$ from the gas wells in north-central PA) and PA site. Shale samples from the NY site contain 19-85 $\mathrm{mg} / \mathrm{kg}$, higher than the concentrations in the shales from the PA site (36-48 $\mathrm{mg} / \mathrm{kg})$. This suggests that our Li concentration data for both formation water and rock might be indicative of illitization of smectite that occurred during burial diagenesis of Marcellus Shale because the Li concentration in clay increases with Li concentration in coexisting fluids during the illite-smectite transition (at least for Mg-Li substitutions; Decarreau et al., 2012; Vigier et al., 2008; Williams and Hervig, 2005). The pore fluid may have been enriched in Li from alteration of K-bentonite ash. The ash is commonly observed as thin beds within the Marcellus Shale (Ver Straeten, 2004).

To explore this hypothesis further, we attempt to calculate the Li concentration in the Paleozoic pore fluid that would have been in equilibrium with clays during Marcellus Shale diagenesis at maximum burial depth, then compare this with the calculated Li concentrations in the formation water using concentrations measured in our study. We use the partition coefficient 
experimentally determined for Mg-smectite (Decarreau et al., 2012), which is correlated with temperature as follows:

$$
\log \mathrm{D}_{\mathrm{Li}}=-\frac{1319}{\mathrm{~T}(\mathrm{~K})}+5.5 \cdot \mathrm{Li}_{\mathrm{aq}}^{-0.0806}
$$

where $\mathrm{D}_{\mathrm{Li}}$ is the smectite-solution partition coefficient defined as $\mathrm{D}_{\mathrm{Li}}=\frac{[\mathrm{Li}]_{\mathrm{clay}}}{[\mathrm{Li}]_{\mathrm{aq}}}$. We note that this experiment was performed on hectorite, which is not the same mineral as common K-rich smectite in the Marcellus Shale. Fig. 10 shows the range of Li concentrations in illite (estimated based on structurally-bound Li at both PA and NY study sites), the median \% of illite in Marcellus Shale (30\%; Wang and Carr, 2012), and Li concentration in formation waters from southwestern PA (solid red line) and north-central PA (dashed black line) (in close proximity with NY site). The differences in maximum burial depth and temperature may also have varied between the two sites, which are important because higher temperatures favor greater Li partitioning from the aqueous phase into the authigenic clay. The ranges in Li concentrations at the two sites are consistent with the maximum burial temperatures, which are generally higher in the east and lower in the southern portion of the Appalachian Basin in this region (Evans et al., 2014). For the PA site, the narrow range of $\mathrm{Li}$ in illite $(110-120 \mathrm{mg} / \mathrm{kg})$, assuming it formed at the usual temperature range of $80-120{ }^{\circ} \mathrm{C}$, could possibly be explained by Li concentrations $(75-$ $101 \mathrm{mg} / \mathrm{L}$ ) in the formation water in this area. On the other hand, a large range in illite-Li at the NY site plausibly implies a larger change in burial temperature, hydrothermal fluid alteration, or degree of folding during uplift and erosion. These processes have been previously documented (Evans et al., 2014). Estimated burial temperatures are based on fluid inclusion data from three cores in the eastern Appalachian Basin, and range from $132^{\circ} \mathrm{C}$ (early quartz) to $233^{\circ} \mathrm{C}$ (late quartz; Evans et al., 2014). Authigenic clays at the NY site formed during precipitation of early to late calcite, and would require a parental fluid with a higher range of Li concentrations (169- 
$282 \mathrm{mg} / \mathrm{L}$ ), similar to our observed values. Our data suggest that the Decarreau et al. (2012) model can be used to estimate Li concentrations in clay minerals associated with illitization, if the temperature during clay formation can be estimated. In short, Li concentration in clay minerals was controlled by Li concentration in pore fluid during authigenic clay formation, which was a temperature-dependent process.

\subsection{Lithium isotopes in a shale-water system}

Many studies show that $\delta^{7} \mathrm{Li}$ in sedimentary formation water is strongly dependent on the magnitude and mechanism of isotopic fractionation resulting from water-rock interactions (Huh

et al., 1998; Chan et al., 2002; Millot et al., 2010b; Vigier et al., 2009). Therefore, it is critical to examine $\mathrm{Li}$ isotopes of formation waters and associated rocks in individual lithologic units in order to better constrain relevant processes occurring within the unit. As discussed in section 4.1.3, preferential incorporation of ${ }^{6} \mathrm{Li}$ into authigenic clay minerals in the Marcellus Shale would result in an enrichment of ${ }^{7} \mathrm{Li}$ in the pore fluid. Such a mechanism has been suggested as an explanation for changes in $\delta^{7} \mathrm{Li}$ of seawater. For example, within 60 million years from the Paleocene to the present, $\delta^{7} \mathrm{Li}$ of seawater rose by $9 \%$ to the present-day value of $\sim 31 \%$ (Misra and Froelich, 2012).

The $\delta^{7} \mathrm{Li}$ values of shale samples from the PA site range from +0.7 to $+4.3 \%$, whereas the average $\delta^{7} \mathrm{Li}$ in formation waters is about $+10 \%$ o (median $=10 \%$; $\left.n=12\right)$. This yields an estimated water-rock isotopic fractionation factor, $\Delta_{\text {solution-solid }}$ of $5.7-9.3 \%$ for Li. Similarly, $\delta^{7} \mathrm{Li}$ values in shales from the NY site range from -2.3 to $+2.9 \%$, and $\delta^{7} \mathrm{Li}$ in formation waters the nearby site in Tioga Co., PA, are $+14.7 \%$ on average $(n=2)$. These values can be combined to give: $\Delta_{\text {solution-solid }}=12-17 \%$. These calculated fractionation factors are rough estimates because they are not calculated directly from $\delta^{7} \mathrm{Li}$ values of the aqueous phase and the resulting 
clays. Many studies have shown that $\mathrm{Li}$ isotopic fractionation during clay formation correlates inversely with temperature (Millot et al., 2010a; Williams and Hervig, 2005). To test whether differences in temperature could explain the different degrees of isotope fractionation at the two study sites, we used several chemical thermometers, including the $\mathrm{Na}-\mathrm{K}-\mathrm{Mg}$ (Giggenbach, 1988) and the Mg/Li (Kharaka and Mariner, 1989; Land and Macpherson, 1992), to estimate the reservoir temperatures during illitization, assuming this diagenetic process is the primarily one controlling Li isotopic fractionation in produced waters of the Marcellus Shale. Water chemistry data from this study and from previous studies (Kolesar Kohl et al., 2014; Rowan et al., 2015) were used. The Na-K-Mg geothermometer consistently predicted similar paleo-temperatures for groups of Marcellus wells in southwestern PA $\left(89^{\circ} \mathrm{C}\right)$ and in north-central PA $\left(83^{\circ} \mathrm{C}\right)$. These temperature values are in similar range of present-day temperatures in well bores, using a representative geothermal gradient $\left(21.5^{\circ} \mathrm{C} / \mathrm{km}\right.$; Shope, 2012): $72^{\circ} \mathrm{C}$ for well depth $=2.4 \mathrm{~km}$ (southwestern PA) and $52^{\circ} \mathrm{C}$ for well depth $=1.5 \mathrm{~km}$ (north-central PA). However, as demonstrated by Land and Macpherson (1992), the Mg/Li geothermometer calculation (Kharaka and Mariner, 1989) results in more reasonable estimated maximum paleo-temperatures of $155 \pm$ $21^{\circ} \mathrm{C}$ and $187 \pm 11^{\circ} \mathrm{C}$ for southwestern PA and north-central PA, respectively. We recognize that some uncertainty remains because the mechanisms of mineral-based chemical thermometers are different for different water-rock systems. Nonetheless, the temperature $(\mathrm{Mg} / \mathrm{Li})$ in southwestern PA is lower than in north-central PA, which is in agreement with fluid inclusion temperatures (Evans et al., 2014) showing higher temperature in the eastern part of the Appalachian Basin. As discussed above, the lithium isotopic fractionation factor in southwestern PA $\left(\Delta_{\text {solution-solid }}=5.7-\right.$ $9.3 \%$ ) is lower than in north-central PA $\left(\Delta_{\text {solution-solid }}=12-17 \%\right.$ ), implying a higher temperature (less fractionation; Millot et al., 2010a; Vigier et al., 2008) in southwestern PA. We suggest that 
the calculated fractionation factors in a shale-water system may reflect multiple processes fractionating the $\mathrm{Li}$ isotopes, rather than a single process, such as illitization during diagenesis. In this region, multiple processes could potentially have affected the lithium isotope systematics including multiple events of subsurface hydrothermal fluid flow leading to multiple generations of illitization (Clauer et al., 2013), tectonic events such as folding and uplift, and circulation by meteoric water. All of these could affect both $\mathrm{Li}$ and $\delta^{7} \mathrm{Li}$ in formation waters, and therefore create difficulties in simple interpretation of the mechanism of $\mathrm{Li}$ isotopic fractionation.

\subsection{Combined Li and Sr isotopes for monitoring fluid sources}

One of many environmental issues related to shale gas development in the USA is the potential contamination of water in overlying shallow aquifers (see reviews by Soeder et al., 2014; Vengosh et al., 2014). Formation water migration through natural fractures or conductive faults due to hydraulic fracturing is unlikely due to low permeability of the bedrock (Flewelling and Sharma, 2014). Previous case studies showed that upward migration of Marcellus formation water (Kolesar Kohl et al., 2014) or gas (Sharma et al. 2015) to Upper Devonian units located at $900-1200 \mathrm{~m}$ above the zone of gas production after hydraulic fracturing was not statistically significant. However, compromised well casing and cements (Davies et al., 2014; Ingraffea et al., 2014) and accidental surface spills of produced water of oil and gas wells in Pennsylvania (Brantley et al., 2014) pose risks of releasing saline formation water into shallow aquifers and surface waters. This study shows that $\delta^{7} \mathrm{Li}$ combined with ${ }^{87} \mathrm{Sr} /{ }^{86} \mathrm{Sr}$ isotopes have the potential to distinguish formation waters from Upper Devonian sandstones and the Marcellus Shale formation waters in case of accidental releases at or near the surface.

Warner et al. (2014) evaluated the application of $\delta^{7} \mathrm{Li}$ to universally identify brines from hydraulically fractured wells and conventional oil and gas wells. Our data extend the range of 
measured $\delta^{7} \mathrm{Li}$ values of Marcellus formation water across the Appalachian Basin, suggesting that baseline data and knowledge of the produced water source region would be required to clearly identify the source of a potential produced water spills. For example, $\delta^{7} \mathrm{Li}$ values in the Marcellus formation water in Tioga County, PA $(+14.3 \%$ and $+15.0 \%$ ) are significantly higher than the previously observed range for Marcellus brine $(+6-+10 \%)$, and in fact fall in the same range of $\delta^{7} \mathrm{Li}$ found in formation water from conventional oil and gas production $(+10-+25 \%$; Warner et al., 2014).

We found that both $\delta^{7} \mathrm{Li}$ and ${ }^{87} \mathrm{Sr} /{ }^{86} \mathrm{Sr}$ of formation water from Upper Devonian (multiple lithologic units) gas wells in Greene Co., PA (Fig. 11b) vary in a narrow range $\left(\delta^{7} \mathrm{Li}=+13.7-\right.$ $\left.+16.5 \% ;{ }^{87} \mathrm{Sr} /{ }^{86} \mathrm{Sr}=0.71977-0.72096\right)$. This range is very different from Marcellus Shale formation water $\left(\delta^{7} \mathrm{Li}=+9.2-+10.4 \% ;{ }^{87} \mathrm{Sr} /{ }^{86} \mathrm{Sr}=0.70998-0.71173\right)$, implying the presence of hydrologic separation between these units in the study area. On the other hand, in Tioga Co., PA (Fig. 11b), Li and Sr isotopic compositions in formation waters from these two reservoirs (Upper Devonian Burket Shale and Middle Devonian Marcellus Shale) do not vary as much as in Greene Co., PA which is possibly explained by the similarity in the lithology of the equilibrated rocks (e.g. shale). Alternatively, the variation in these two sites could reflect differences in the degree of fluid communication between stratigraphic units in these two areas of the Appalachian Basin, with a greater degree of faulting and tectonically-driven fluid flow in the northeastern section.

We further examine the use of $\delta^{7} \mathrm{Li}$ and ${ }^{87} \mathrm{Sr} /{ }^{86} \mathrm{Sr}$ to monitor potential contamination of surface water in case of accidental release of Upper or Middle Devonian formation waters. We use ${ }^{87} \mathrm{Sr} /{ }^{86} \mathrm{Sr}$ values from stream waters in the same location of these gas wells (Kolesar Kohl et al. 2014) and the average $\delta^{7} \mathrm{Li}$ in major river waters around the world (+23\%) to build the 
conservative mixing curves (Fig. 11) predicting the variation in $\delta^{7} \mathrm{Li}$ and ${ }^{87} \mathrm{Sr} /{ }^{86} \mathrm{Sr}$ in a hypothetical stream water if it is mixed with Upper Devonian (dotted line) and Middle Devonian (dashed line) formation waters. The $\delta^{7} \mathrm{Li}$ values in rivers globally ranges from +16 to $+29 \%$ o (Huh et al., 1998) and seasonal variations in ${ }^{87} \mathrm{Sr} /{ }^{86} \mathrm{Sr}$ are very small (within the symbol in Fig. 11). The $\delta^{7} \mathrm{Li}$ and ${ }^{87} \mathrm{Sr} /{ }^{86} \mathrm{Sr}$ systems can distinguish Middle Devonian (Marcellus) brine from the Upper Devonian brine. Riverine $\delta^{7} \mathrm{Li}$ values are typically higher than groundwater $\delta^{7} \mathrm{Li}$ values (e.g. +6.7 to +9.4 ; Liu et al., 2015) which are similar to formation water $\delta^{7} \mathrm{Li}$ values. Thus, fingerprinting formation water and groundwater mixing requires a comprehensive multiple isotope approach, and site-specific characterization of formation water. This study suggests that

establishing baseline geochemical and isotopic data (e.g., $\delta^{7} \mathrm{Li}$ and ${ }^{87} \mathrm{Sr} /{ }^{86} \mathrm{Sr}$ ) for surface water in regions of future shale gas development may be valuable for monitoring the long-term impacts of formation waters on fresh-water aquifers.

\section{Conclusions}

This study examined $\mathrm{Li}$ content and $\delta^{7} \mathrm{Li}$ in shale rocks and formation waters of the Marcellus Shale to delineate Li sources and isotopic fractionation resulting from detrital inputs and water-rock interaction during diagenesis. Marcellus shale rocks from two sites display negative correlations of $\delta^{7} \mathrm{Li}$ vs. $\mathrm{Li}$ and $\delta^{7} \mathrm{Li}$ vs. depth which more likely record the progressive weathering regime in the region during deposition. The most weathered and clay rich minerals with isotopically light Li are found in the upper portions of Marcellus Shale. Diagenetic illitesmectite transition could also have affected, in part, the bulk Li content and isotope ratios of the Marcellus Shale and adjacent units.

Sequential extraction experiments were conducted to determine the relative distribution of $\mathrm{Li}$ in different mineral reservoirs. The largest fraction of the $\mathrm{Li}$ was found in the insoluble 
residue which likely consists primarily of silicate minerals. The second largest Li reservoir ( $<20 \%$ of total $\mathrm{Li}$ ) in shales is the oxidizable fraction, chemically bonded with organic matter and/or sulfide minerals. Further investigation is needed to understand the speciation of Li in organic matter and whether Li could also be present in pyrite framboids. Diagenetic carbonate precipitation might in part dilute the total $\mathrm{Li}$ in shale rocks but not isotopic composition because $\mathrm{Li}$ content in carbonate minerals is very low $(<2 \%$ of total $\mathrm{Li})$.

Spatial variation in $\mathrm{Li}$ content and $\delta^{7} \mathrm{Li}$ in formation waters from southwestern PA and north-central PA suggests that Marcellus formation water is not homogeneous across the Appalachian Basin. This heterogeneity could reflect the differences in the mineralogy of the host shale, or differences in burial and thermal history. The relatively small range of $\delta^{7} \mathrm{Li}$ and ${ }^{87} \mathrm{Sr} /{ }^{86} \mathrm{Sr}$ of Upper Devonian and Middle Devonian formation waters in the northeast part of the basin suggests increased mixing and fewer hydrologic barriers between these stratigraphic units in the northeast compared to southwestern Pennsylvania, possibly a result of differences in tectonically-driven faulting and fluid flow. Establishing baseline geochemical and isotopic data for surface water and site specific characterization of formation water in regions of future shale gas development may be valuable for monitoring the long-term impacts of formation waters on fresh-water aquifers.

\section{Acknowledgments}

This work was supported by the U.S. Department of Energy, Office of Fossil Energy, as the National Energy Technology Laboratory's ongoing research under the RES contract DEFE0004000 (RCC, BWS). We thank Dan Bain for technical support with ICP-MS analysis, and Emily Burt for assistance with sample preparation for Sr isotopes. We are grateful for 
constructive comments and suggestions from two anonymous reviewers. Jerome Gaillardet is thanked for editorial handling and useful suggestions. We also thank the operating companies for generously donating the drill core and providing access to water samples that were used in this study. The Eastern Energy Resources Program at the U.S. Geological Survey contributed to collection of water samples. We thank the University of Kansas, Department of Geology and the University of Kansas Endowment Association for support (GLM). This research was supported in part by an appointment to the National Energy Technology Laboratory Research Participation Program, sponsored by the U.S. Department of Energy and administered by the Oak Ridge Institute for Science and Education.

\section{References}

Aydin, M.G., Engelder, T., 2014. Revisiting the Hubbert-Rubey pore pressure model for overthrust faulting: Inferences from bedding-parallel detachment surfaces within Middle Devonian gas shale, the Appalachian Basin, USA. Journal of Structural Geology, 69, Part B: 519-537.

Bagheri, R. et al., 2014. Hydrochemical and isotopic $\left(\delta^{18} \mathrm{O}, \delta^{2} \mathrm{H},{ }^{87} \mathrm{Sr} /{ }^{86} \mathrm{Sr}, \delta^{37} \mathrm{Cl}\right.$ and $\left.\delta^{81} \mathrm{Br}\right)$ evidence for the origin of saline formation water in a gas reservoir. Chemical Geology, 384: 62-75.

Barnes, E.M., Weis, D., Groat, L.A., 2012. Significant Li isotope fractionation in geochemically evolved rare element-bearing pegmatites from the Little Nahanni Pegmatite Group, NWT, Canada. Lithos, 132-133: 21-36.

Blakey, R., 2013. North America Paeogeography. http://cpgeosystems.com/nam.html (accessed 06/25/2015).

Blatter, D.L., Carmichael, I.S., 1998. Plagioclase-free andesites from Zitacuaro (Michoacan), Mexico: petrology and experimental constraints. Contributions to Mineralogy and Petrology, 132(2): 121-138.

Blauch, M., Myers, R., Moore, T., Lipinski, B., Houston, N., 2009. Marcellus Shale post-frac flowback waters - Where is all the salt coming from and what are the implications?, SPE Eastern Regional Meeting.

Bottomley, D.J. et al., 1999. The origin and evolution of Canadian Shield brines: evaporation or freezing of seawater? New lithium isotope and geochemical evidence from the Slave craton. Chemical Geology, 155(3-4): 295-320.

Brantley, S.L. et al., 2014. Water resource impacts during unconventional shale gas development: The Pennsylvania experience. International Journal of Coal Geology, 126: 140-156. 
Bryant, C.J., McCulloch, M.T., Bennett, V.C., 2003. Impact of matrix effects on the accurate measurement of Li isotope ratios by inductively coupled plasma mass spectrometry (MCICP-MS) under "cold" plasma conditions. Journal of Analytical Atomic Spectrometry, 18(7): 734-737.

Burton, K.W., Vigier, N., 2012. Lithium Isotopes as Tracers in Marine and Terrestrial Environments. In: Baskaran, M. (Ed.), Handbook of Environmental Isotope Geochemistry. Advances in Isotope Geochemistry. Springer Berlin Heidelberg, pp. 4159.

Capo, R.C. et al., 2014. The strontium isotopic evolution of Marcellus Formation produced waters, southwestern Pennsylvania. International Journal of Coal Geology, 126: 57-63.

Chan, L.-H., Starinsky, A., Katz, A., 2002. The behavior of lithium and its isotopes in oilfield brines: Evidence from the Heletz-Kokhav field, Israel. Geochim. Cosmochim. Acta 66, 615-623.

Chan, L.-H., Leeman, W.P., Plank, T., 2006. Lithium isotopic composition of marine sediments. Geochemistry, Geophysics, Geosystems, 7(6): Q06005.

Chapman, E.C. et al., 2012. Geochemical and strontium isotope characterization of produced waters from Marcellus Shale natural gas extraction. Environmental Science \& Technology, 46(6): 3545-53.

Chetel, L.M. et al., 2011. Paleogeographic reconstruction of the Eocene Idaho River, North American Cordillera. Geological Society of America Bulletin, 123(1-2): 71-88.

Choi, M.S. et al., 2013. Precise determination of the lithium isotope ratio in geological samples using MC-ICP-MS with cool plasma. Journal of Analytical Atomic Spectrometry, 28(4): 505-509.

Clauer, N. et al., 2013. K-Ar dating and $\delta^{18} \mathrm{O}-\delta \mathrm{D}$ characterization of nanometric illite from Ordovician K-bentonites of the Appalachians: Illitization and the Acadian-Alleghenian tectonic activity. American Mineralogist, 98(11-12): 2144-2154.

Davies, R.J. et al., 2014. Oil and gas wells and their integrity: Implications for shale and unconventional resource exploitation. Marine and Petroleum Geology, 56: 239-254.

Decarreau, A. et al., 2012. Partitioning of lithium between smectite and solution: An experimental approach. Geochimica et Cosmochimica Acta, 85: 314-325.

Dellinger, M. et al., 2014. Lithium isotopes in large rivers reveal the cannibalistic nature of modern continental weathering and erosion. Earth and Planetary Science Letters, 401: 359-372.

Deng, Y., Zhang, C., Wei, X., 2014. Influence of lithium sulfate addition on the properties of Portland cement paste. Construction and Building Materials 50, 457-462.

Dresel, P.E., Rose, A.W., 2010. Chemistry and origin of oil and gas well brines in western Pennsylvania. Pennsylvania Geol Surv, $4^{\text {th }}$ series Open-File Report OFOG 10-01,0, 48 p., https://edx.netl.doe.gov/dataset/chemistry-and-origin-of-oil-and-gas-well-brines-inwestern-pennsylvania/revision_resource/7d1a3053-178e-4852-84ec-559b1732a2b0, accessed 10/30/2015.

Evans, M.A., Bebout, G.E., Brown, C.H., 2012. Changing fluid conditions during folding: An example from the central Appalachians. Tectonophysics, 576-577: 99-115.

Evans, M.A., DeLisle, A., Leo, J., Lafonte, C.J., 2014. Deformation conditions for fracturing in the Middle Devonian sequence of the central Appalachians during the Late Paleozoic Alleghenian orogeny. AAPG Bulletin, 98(11): 2263-2299. 
Flewelling, S.A., Sharma, M., 2014. Constraints on Upward Migration of Hydraulic Fracturing Fluid and Brine. Groundwater, 52(1): 9-19.

Giggenbach, W.F., 1988. Geothermal solute equilibria. derivation of Na-K-Mg-Ca geoindicators. Geochimica et cosmochimica acta, 52(12): 2749-2765.

Govindaraju, K., 1994. Compilation of working values and sample description for 383 geostandards. Geostandards Newsletter, 18: 1-158.

Gu, P., Beaudoin, J.J., 1997. Lithium salt-based additives for early strength-enhancement of ordinary Portland cement-high alumina cement paste. Journal of Materials Science Letters 16, 696-698.

Haluszczak, L.O., Rose, A.W., Kump, L.R., 2013. Geochemical evaluation of flowback brine from Marcellus gas wells in Pennsylvania, USA. Applied Geochemistry, 28: 55-61.

Hayes, T., 2009. Sampling and analysis of water streams associated with the development of Marcellus shale gas. Marcellus Shale Coalition: Des Plaines, IL, Gas Technology Institute.

Hofstra, A., Todorov, T., Mercer, C., Adams, D., Marsh, E., 2013. Silicate Melt Inclusion Evidence for Extreme Pre-eruptive Enrichment and Post-eruptive Depletion of Lithium in Silicic Volcanic Rocks of the Western United States: Implications for the Origin of Lithium-Rich Brines. Economic Geology, 108(7): 1691-1701.

Holland, H.D., 1984. The chemical evolution of the atmosphere and oceans. Princeton University Press.

Hosterman, J.W., Whitlow, S.I., 1983. Clay mineralogy of Devonian shales in the Appalachian Basin. U.S. Geol. Surv. Prof. Paper 1298, 1-31.

Huang, K.-F. et al., 2010. Low-memory, small sample size, accurate and high-precision determinations of lithium isotopic ratios in natural materials by MC-ICP-MS. Journal of Analytical Atomic Spectrometry, 25(7): 1019-1024.

Huh, Y., Chan, L.-H., Zhang, L., Edmond, J.M., 1998. Lithium and its isotopes in major world rivers: implications for weathering and the oceanic budget. Geochimica et Cosmochimica Acta, 62(12): 2039-2051.

Ingraffea, A.R., Wells, M.T., Santoro, R.L., Shonkoff, S.B.C., 2014. Assessment and risk analysis of casing and cement impairment in oil and gas wells in Pennsylvania, 20002012. Proceedings of the National Academy of Sciences of the United States of America, 111(30): 10955-10960.

James, R.H., Palmer, M.R., 2000. The lithium isotope composition of international rock standards. Chemical Geology, 166(3-4): 319-326.

Jeffcoate, A.B., Elliott, T., Thomas, A., Bouman, C., 2004. Precise/ Small Sample Size Determinations of Lithium Isotopic Compositions of Geological Reference Materials and Modern Seawater by MC-ICP-MS. Geostandards and Geoanalytical Research, 28(1): 161-172.

Johnson, J.D., Graney, J.R., 2015. Fingerprinting Marcellus Shale waste products from Pb isotope and trace metal perspectives. Applied Geochemistry, doi.org/10.1016/j.apgeochem.2014.08.002.

Ketris, M.P., Yudovich, Y.E., 2009. Estimations of Clarkes for Carbonaceous biolithes: World averages for trace element contents in black shales and coals. International Journal of Coal Geology, 78(2): 135-148.

Kharaka, Y., Hanor, J., 2003. Deep fluids in the continents: I. Sedimentary basins. Treatise on geochemistry, 5: 499-540. 
Kharaka, Y., Mariner, R., 1989. Chemical Geothermometers and Their Application to Formation Waters from Sedimentary Basins. In: Naeser, N., McCulloh, T. (Eds.), Thermal History of Sedimentary Basins. Springer New York, pp. 99-117.

Kohl, D., Slingerland, R., Arthur, M., Bracht, R., Engelder, T., 2014. Sequence stratigraphy and depositional environments of the Shamokin (Union Springs) Member, Marcellus Formation, and associated strata in the middle Appalachian Basin. AAPG Bulletin, 98(3): 483-513.

Kolesar Kohl, C.A. et al., 2014. Strontium Isotopes Test Long-Term Zonal Isolation of Injected and Marcellus Formation Water after Hydraulic Fracturing. Environmental Science \& Technology, 48(16): 9867-9873.

Kurtz, A.C., Derry, L.A., Chadwick, O.A., Alfano, M.J., 2000. Refractory element mobility in volcanic soils. Geology 28, 683-686.

Land, L., Macpherson, G., 1992. Geothermometry from brine analyses: lessons from the Gulf Coast, USA. Applied geochemistry, 7(4): 333-340.

Lash, G.G., Blood, D.R., 2014. Organic matter accumulation, redox, and diagenetic history of the Marcellus Formation, southwestern Pennsylvania, Appalachian basin. Marine and Petroleum Geology, 57: 244-263.

Lash, G.G., Engelder, T., 2011. Thickness trends and sequence stratigraphy of the Middle Devonian Marcellus Formation, Appalachian Basin: Implications for Acadian foreland basin evolution. AAPG Bulletin, 95(1): 61-103.

Laughrey, C., Ruble, T., Lemmens, H., Kostelnik, J., Butcher, A., Walker, G., Knowles, W., 2011. AV Black Shale Diagenesis: Insights from Integrated High-Definition Analyses of Post-Mature Marcellus Formation Rocks, Northeastern Pennsylvania: http://www.searchanddiscovery.com/documents/2011/110150laughrey/ndx_laughrey.pdf (Accessed October 19, 2015).

Liu, X.M., Rudnick, R.L., Hier-Majumder, S., Sirbescu, M.L.C., 2010. Processes controlling lithium isotopic distribution in contact aureoles: A case study of the Florence County pegmatites, Wisconsin. Geochemistry, Geophysics, Geosystems, 11(8).

Liu, X.-M., Wanner, C., Rudnick, R.L., McDonough, W.F., 2015. Processes controlling $\delta^{7}$ Li in rivers illuminated by study of streams and groundwaters draining basalts. Earth and Planetary Science Letters, 409: 212-224.

Macpherson, G.L., 2015. Lithium in Fluids from Paleozoic-aged Reservoirs, Appalachian Plateau Region, USA. Applied Geochemistry. doi: http://dx.doi.org/10.1016/j.apgeochem.2015.04.013

Macpherson, G.L. et al., 2014. Temperature-dependent Li isotope ratios in Appalachian Plateau and Gulf Coast Sedimentary Basin saline water. Geofluids, 14: 419-429.

Magna, T., Wiechert, U.H., Halliday, A.N., 2004. Low-blank isotope ratio measurement of small samples of lithium using multiple-collector ICPMS. International Journal of Mass Spectrometry, 239(1): 67-76.

Marriott, C.S., Henderson, G.M., Crompton, R., Staubwasser, M., Shaw, S., 2004. Effect of mineralogy, salinity, and temperature on $\mathrm{Li} / \mathrm{Ca}$ and $\mathrm{Li}$ isotope composition of calcium carbonate. Chemical Geology, 212(1): 5-15

McCaffrey, M., Lazar, B., Holland, H., 1987. The evaporation path of seawater and the coprecipitation of $\mathrm{Br}^{-}$and $\mathrm{K}^{+}$with halite. Journal of Sedimentary Research, 57(5): 928937. 
Milliken, K.L., Rudnicki, M., Awwiller, D.N., Zhang, T., 2013. Organic matter-hosted pore system, Marcellus Formation (Devonian), Pennsylvania. AAPG Bulletin, 97(2): 177-200.

Millot, R., Girard, J., 2007. Lithium isotope fractionation during adsorption onto mineral surfaces, Clay in natural \& engineered barriers for radioactive waste confinement-3rd International Meeting-September 17-18, 2007, Lille, France.

Millot, R., Guerrot, C., Innocent, C., Négrel, P., Sanjuan, B., 2011. Chemical, multi-isotopic (Li$\mathrm{B}-\mathrm{Sr}-\mathrm{U}-\mathrm{H}-\mathrm{O})$ and thermal characterization of Triassic formation waters from the Paris Basin. Chemical Geology, 283(3-4): 226-241.

Millot, R., Guerrot, C., Vigier, N., 2004. Accurate and High-Precision Measurement of Lithium Isotopes in Two Reference Materials by MC-ICP-MS. Geostandards and Geoanalytical Research, 28(1): 153-159.

Millot, R., Scaillet, B., Sanjuan, B., 2010a. Lithium isotopes in island arc geothermal systems: Guadeloupe, Martinique (French West Indies) and experimental approach. Geochimica et Cosmochimica Acta, 74(6): 1852-1871.

Millot, R., Vigier, N., Gaillardet, J., 2010b. Behaviour of lithium and its isotopes during weathering in the Mackenzie Basin, Canada. Geochimica et Cosmochimica Acta, 74(14): 3897-3912.

Misra, S., Froelich, P.N., 2009. Measurement of lithium isotope ratios by quadrupole-ICP-MS: application to seawater and natural carbonates. Journal of Analytical Atomic Spectrometry, 24(11): 1524-1533.

Misra, S., Froelich, P.N., 2012. Lithium Isotope History of Cenozoic Seawater: Changes in Silicate Weathering and Reverse Weathering. Science, 335(6070): 818-823.

Moriguti, T., Nakamura, E., 1998. Across-arc variation of Li isotopes in lavas and implications for crust/mantle recycling at subduction zones. Earth and Planetary Science Letters, 163(1-4): 167-174.

Mosier, 1988. Geochemical characterization of solid-phase materials in the Central Oklahoma Aquifer. In: S. Christenson and J.S. Havens (Eds.), Ground-Water-Quality Assessment of the Central Oklahoma Aquifer, Oklahoma: Results of Investigations. U.S. Geological Survey Water-Supply Paper 2357-A, pp. 71-105.

Nishio, Y., Nakai, S.i., 2002. Accurate and precise lithium isotopic determinations of igneous rock samples using multi-collector inductively coupled plasma mass spectrometry. Analytica Chimica Acta, 456(2): 271-281.

Okumura, M., Kitano, Y., 1986. Coprecipitation of alkali metal ions with calcium carbonate. Geochimica et Cosmochimica Acta, 50(1): 49-58.

Parrish, C.B., 2013. Insights into the Appalachian Basin Middle Devonian Depositional System from U-Pb Zircon Geochronology of Volcanic Ashes in the Marcellus Shale and Onondaga Limestone. West Virginia University.

Penniston-Dorland, S.C., Sorensen, S.S., Ash, R.D., Khadke, S.V., 2010. Lithium isotopes as a tracer of fluids in a subduction zone mélange: Franciscan Complex, CA. Earth and Planetary Science Letters, 292(1-2): 181-190.

Phan, T.T. et al., 2015. Trace metal distribution and mobility in drill cuttings and produced waters from Marcellus Shale gas extraction: Uranium, arsenic, barium. Applied Geochemistry, 60: 89-103.

Pistiner, J.S., Henderson, G.M., 2003. Lithium-isotope fractionation during continental weathering processes. Earth and Planetary Science Letters, 214(1-2): 327-339. 
Pogge von Strandmann, P.A.E., Burton, K.W., James, R.H., van Calsteren, P., Gislason, S.R., 2010. Assessing the role of climate on uranium and lithium isotope behaviour in rivers draining a basaltic terrain. Chemical Geology, 270(1-4): 227-239.

Pogge von Strandmann, P.A.E. et al., 2006. Riverine behaviour of uranium and lithium isotopes in an actively glaciated basaltic terrain. Earth and Planetary Science Letters, 251(1-2): 134-147.

Pogge von Strandmann, P.A.E., Jenkyn, H.C., Woodfine, R.G., 2013. Lithium isotope evidence for enhanced weathering during Oceanic Anoxic Event 2. Nature Geosci., 6: 668 - 672.

Qi, H.P., Taylor, P.D.P., Berglund, M., De Bièvre, P., 1997. Calibrated measurements of the isotopic composition and atomic weight of the natural $\mathrm{Li}$ isotopic reference material IRMM-016. International Journal of Mass Spectrometry and Ion Processes, 171(1-3): 263-268.

Qiu, L., Rudnick, R.L., Ague, J.J., McDonough, W.F., 2011. A lithium isotopic study of subgreenschist to greenschist facies metamorphism in an accretionary prism, New Zealand. Earth and Planetary Science Letters, 301(1-2): 213-221.

Romer, R.L., Meixner, A., 2014. Lithium and boron isotopic fractionation in sedimentary rocks during metamorphism - The role of rock composition and protolith mineralogy. Geochimica et Cosmochimica Acta, 128: 158-177.

Rosner, M. et al., 2007. A Simplified, Accurate and Fast Method for Lithium Isotope Analysis of Rocks and Fluids, and $\delta^{7} \mathrm{Li}$ Values of Seawater and Rock Reference Materials.

Geostandards and Geoanalytical Research, 31(2): 77-88.

Rowan, E. L., Engle, M. A., Kraemer, T. F., Schroeder, K. T., Hammack, R. W., and Doughten, M. W., 2015. Geochemical and isotopic evolution of water produced from Middle Devonian Marcellus Shale gas wells, Appalachian Basin, Pennsylvania. AAPG Bulletin, v. 99, p. 181-206.

Rudnick, R., Gao, S., 2003. Composition of the continental crust. Treatise on geochemistry, 3: 1 64.

Rudnick, R.L., Tomascak, P.B., Njo, H.B., Gardner, L.R., 2004. Extreme lithium isotopic fractionation during continental weathering revealed in saprolites from South Carolina. Chemical Geology 212, 45-57.

Ryan, J.G., Kyle, P.R., 2004. Lithium abundance and lithium isotope variations in mantle sources: insights from intraplate volcanic rocks from Ross Island and Marie Byrd Land (Antarctica) and other oceanic islands. Chemical Geology, 212(1-2): 125-142.

Sauzéat, L., Rudnick, R.L., Chauvel, C., Garçon, M., Tang, M., 2015. New perspectives on the $\mathrm{Li}$ isotopic composition of the upper continental crust and its weathering signature. Earth. Planet. Sci. Lett. 428, 181-192.

Sharma, S., Bowman, L., Schroeder, K., Hammack, R., 2015. Assessing changes in gas migration pathways at a hydraulic fracturing site: Example from Greene County, Pennsylvania, USA. Applied Geochemistry.

Shope, E.N., 2012. A detailed approach to low-grade geothermal resources in the Appalachian Basin of New York and Pennsylvania: Heterogeneities within the geologic model and their effect on geothermal resource assessment, Cornell University, $169 \mathrm{pp}$. http://hdl.handle.net/1813/31206

Soeder, D.J. et al., 2014. An approach for assessing engineering risk from shale gas wells in the United States. International Journal of Coal Geology, 126: 4-19. 
Starkey, H.C., 1982. The role of clays in fixing lithium. U.S. Geological Survey Bulletin 1278-F, F1-F11.

Staub, P., 2014. Clay mineralogy of the marcellus and utica shales: Implications for fluid development via cation exchange, University at Buffalo, ProQuest LLC.

Stewart, B.W. et al., 2015. Origin of brines, salts and carbonate from shales of the Marcellus Formation: Evidence from geochemical and $\mathrm{Sr}$ isotope study of sequentially extracted fluids. Applied Geochemistry.

Tang, Y.-J., Zhang, H.-F., Ying, J.-F., 2007. Review of the lithium isotope system as a geochemical tracer. International Geology Review, 49(4): 374-388.

Taylor, S.R., McLennan, S.M., 1985. The continental crust: its composition and evolution. Blackwell Scientific Pub., Palo Alto, CA. OSTI Identifier 6582885.

Teng, F.-Z., McDonough, W.F., Rudnick, R.L., Walker, R.J., 2006. Diffusion-driven extreme lithium isotopic fractionation in country rocks of the Tin Mountain pegmatite. Earth and Planetary Science Letters, 243(3-4): 701-710.

Teng, F.-Z., McDonough, W.F., Rudnick, R.L., Wing, B.A., 2007. Limited lithium isotopic fractionation during progressive metamorphic dehydration in metapelites: A case study from the Onawa contact aureole, Maine. Chemical Geology, 239(1-2): 1-12.

Teng, F.Z. et al., 2004. Lithium isotopic composition and concentration of the upper continental crust. Geochimica et Cosmochimica Acta, 68(20): 4167-4178.

Tomascak, P.B., Carlson, R.W., Shirey, S.B., 1999. Accurate and precise determination of Li isotopic compositions by multi-collector sector ICP-MS. Chemical Geology, 158(1-2): 145-154.

Vengosh, A., Jackson, R.B., Warner, N., Darrah, T.H., Kondash, A., 2014. A Critical Review of the Risks to Water Resources from Unconventional Shale Gas Development and Hydraulic Fracturing in the United States. Environmental Science \& Technology.

Ver Straeten, C.A., 2004. K-bentonites, volcanic ash preservation, and implications for Early to Middle Devonian volcanism in the Acadian orogen, eastern North America. Geological Society of America Bulletin, 116(3-4): 474-489.

Vigier, N. et al., 2008. Quantifying Li isotope fractionation during smectite formation and implications for the Li cycle. Geochimica et Cosmochimica Acta, 72(3): 780-792.

Vigier, N., Gislason, S.R., Burton, K.W., Millot, R., Mokadem, F., 2009. The relationship between riverine lithium isotope composition and silicate weathering rates in Iceland. Earth and Planetary Science Letters, 287(3-4): 434-441.

Wall, A.J. et al., 2013. High throughput method for Sr extraction from variable matrix waters and $87 \mathrm{Sr} / 86 \mathrm{Sr}$ isotope analysis by MC-ICP-MS. Journal of Analytical Atomic Spectrometry, 28(8): 1338-1344.

Wang, G., Carr, T.R., 2012. Methodology of organic-rich shale lithofacies identification and prediction: A case study from Marcellus Shale in the Appalachian basin. Computers \& Geosciences, 49: 151-163.

Wang, G., Carr, Timothy R., 2013. Organic-rich Marcellus Shale lithofacies modeling and distribution pattern analysis in the Appalachian Basin. AAPG Bulletin, 97(12): 21732205.

Wanner, C., Sonnenthal, E.L., Liu, X.-M., 2014. Seawater $\delta^{7} \mathrm{Li}$ : A direct proxy for global $\mathrm{CO}_{2}$ consumption by continental silicate weathering? Chemical Geology, 381: 154-167. 
Warner, N.R. et al., 2014. New Tracers Identify Hydraulic Fracturing Fluids and Accidental Releases from Oil and Gas Operations. Environmental Science \& Technology, 48(21): $12552-12560$.

Warner, N.R. et al., 2012. Geochemical evidence for possible natural migration of Marcellus Formation brine to shallow aquifers in Pennsylvania. Proc. Natl. Acad. Sci. USA, 109(30): 11961-11966.

Werne, J.P., Sageman, B.B., Lyons, T.W., Hollander, D.J., 2002. An integrated assessment of a "type euxinic" deposit: Evidence for multiple controls on black shale deposition in the middle Devonian Oatka Creek formation. American Journal of Science, 302(2): 110-143.

Whitacre, J.V., 2014. Carnegie Museum of Natural History Pennsylvania Unconventional Natural Gas Wells Geodatabase (v.2014-Q4) [Computer File]. Carnegie Museum of Natural History, Pittsburgh, PA <http://www.carnegiemnh.org/science/default.aspx?id=18716> (accessed 13.07.14).

Williams, L.B., Hervig, R.L., 2005. Lithium and boron isotopes in illite-smectite: The importance of crystal size. Geochimica et Cosmochimica Acta, 69(24): 5705-5716.

Williams, L.B., Środoń, J., Huff, W.D., Clauer, N., Hervig, R.L., 2013. Light element distributions $(\mathrm{N}, \mathrm{B}, \mathrm{Li})$ in Baltic Basin bentonites record organic sources. Geochimica et Cosmochimica Acta, 120: 582-599.

You, C.F., Chan, L.H., 1996. Precise determination of lithium isotopic composition in low concentration natural samples. Geochimica et Cosmochimica Acta, 60(5): 909-915. 


\section{TABLES}

Table 1 Lithium concentrations and isotopic compositions $\left(\delta^{7} \mathrm{Li}\right)$ of reference rock standards and in-house saline water standards

\begin{tabular}{|c|c|c|c|c|c|c|}
\hline \multirow[b]{2}{*}{ Sample } & \multirow[b]{2}{*}{ Type } & \multicolumn{2}{|c|}{ Measured values in this study } & \multicolumn{3}{|c|}{ Reported values } \\
\hline & & $\begin{array}{c}{[\mathrm{Li}]^{\mathrm{a}}} \\
(\mathrm{ppm})\end{array}$ & $\begin{array}{c}\delta^{7} \mathrm{Li}^{\mathrm{a}} \pm 2 \mathrm{SD} \\
(\% 0)\end{array}$ & $\begin{array}{c}{[\mathrm{Li}]^{\mathrm{b}} \pm 2 \mathrm{SD}} \\
(\mathrm{ppm})\end{array}$ & $\begin{array}{c}\delta^{7} \mathrm{Li}^{\mathrm{b}} \pm 2 \mathrm{SD} \\
(\% 0)\end{array}$ & References \\
\hline \multicolumn{7}{|c|}{$\underline{\text { Rock reference standards }}$} \\
\hline \multirow[t]{3}{*}{ BCR-1 } & Basalt & 12.20 & $2.5 \pm 0.5$ & $12.9 \pm 0.4$ & & (Govindaraju, 1994) \\
\hline & & 13.50 & $2.4 \pm 0.1$ & 12.5 & $2.38 \pm 0.52$ & (Magna et al., 2004) \\
\hline & & 12.11 & $2.5 \pm 0.3$ & & $2.0 \pm 0.7$ & (Teng et al., 2006) \\
\hline \multirow[t]{3}{*}{ JG-2 } & Granite & 40.90 & $0.0 \pm 0.2$ & 42.973 & $0.24 \pm 0.2$ & (Jeffcoate et al., 2004) \\
\hline & & & & 39.000 & $-0.7 \pm 0.9$ & (Pistiner and Henderson, 2003) \\
\hline & & & & 41.000 & $-0.4 \pm 0.2$ & (James and Palmer, 2000) \\
\hline \multirow[t]{4}{*}{ G-2 } & Granite & 31.75 & $-0.03 \pm 0.2$ & $34 \pm 4$ & & (Govindaraju, 1994) \\
\hline & & 31.33 & $-0.27 \pm 0.4$ & $\mathrm{n} / \mathrm{a}$ & $0.3 \pm 1.7$ & (Barnes et al., 2012) \\
\hline & & 30.18 & $0.52 \pm 0.4$ & 31.8 & $1.2 \pm 0.4$ & (James and Palmer, 2000) \\
\hline & & & & & $0.3 \pm 1.9$ & (Liu et al., 2010) \\
\hline \multirow[t]{2}{*}{ JR-2 } & Rhyolite & 77.40 & 4.2 & 78.6 & $3.84 \pm 0.18$ & (Magna et al., 2004) \\
\hline & & & & 73.9 & $3.9 \pm 0.8$ & (James and Palmer, 2000) \\
\hline \multirow[t]{2}{*}{ AGV-1 } & Andesite & 11.28 & $4.34 \pm 0.1$ & $12 \pm 2$ & & (Govindaraju, 1994) \\
\hline & & 10.66 & $4.48 \pm 0.2$ & & $4.6 \pm 0.7$ & (Liu et al., 2010) \\
\hline \multirow[t]{3}{*}{ SGR-1 } & Shale & 132.3 & $4.43 \pm 0.1$ & $147 \pm 26$ & & (Govindaraju, 1994) \\
\hline & & 134.6 & $4.69 \pm 0.1$ & & & \\
\hline & & 136.1 & $5.11 \pm 0.2$ & & & \\
\hline \multirow{2}{*}{ JB3 } & Basalt & 6.81 & 3.5 & 7.55 & $3.94 \pm 0.29$ & (Nishio and Nakai, 2002) \\
\hline & & 6.70 & 3.9 & & & \\
\hline \multicolumn{7}{|c|}{ In-house saline water standards and seawater } \\
\hline \multirow[t]{3}{*}{ AP-MD002 } & Marcellus Fm. & & $9.7 \pm 0.1$ & & $9.48 \pm 0.17$ & \\
\hline & & & 9.9 & & $9.51 \pm 0.18$ & \\
\hline & & & & & $9.54 \pm 0.16$ & \\
\hline \multirow{5}{*}{ WA-A25 } & Marcellus Fm. & & $9.4 \pm 0.1$ & & $9.32 \pm 0.15$ & \\
\hline & & & $9.4 \pm 0.2$ & & $9.38 \pm 0.16$ & (Macpherson et al., 2014) \\
\hline & & & $9.4 \pm 0.1$ & & & \\
\hline & & & $9.8 \pm 0.2$ & & & \\
\hline & & & $9.6 \pm 0.2$ & & & \\
\hline \multirow[t]{11}{*}{ S9148 } & Seawater ${ }^{\S}$ & 0.160 & $32.0 \pm 0.1$ & & $29.3 \pm 0.9$ & (Nishio and Nakai, 2002) \\
\hline & Gulf of Mexico & & $32.0 \pm 0.1$ & & $30.55 \pm 0.45$ & (Choi et al., 2013) \\
\hline & & & $32.3 \pm 0.2$ & & $30.73 \pm 0.15$ & (Huang et al., 2010) \\
\hline & & & $32.1 \pm 0.4$ & & $30.64 \pm 0.44$ & (Rosner et al., 2007) \\
\hline & & & $32.1 \pm 0.5$ & & $30.88 \pm 0.12$ & (Huang et al., 2010) \\
\hline & & & & & $30.84 \pm 0.19$ & (Rosner et al., 2007) \\
\hline & & & & & $31.8 \pm 1.9$ & (Tomascak et al., 1999) \\
\hline & & & & & $29.97 \pm 0.72$ & (Moriguti and Nakamura, 1998) \\
\hline & & & & & 32.42 & (You and Chan, 1996) \\
\hline & & & & & $30.75 \pm 0.41$ & (Misra and Froelich, 2009) \\
\hline & & & & & $31.3 \pm 0.9$ & $\begin{array}{c}\text { (Pogge von Strandmann et al., } \\
\text { 2010) }\end{array}$ \\
\hline
\end{tabular}


Table 2 Lithium concentrations of sequentially extracted fractions; lithium isotopic composition of samples from the Marcellus Shale, Onondaga limestone, and Oriskany sandstone.

\begin{tabular}{|c|c|c|c|c|c|c|c|c|c|c|c|c|c|c|c|c|c|c|c|c|c|}
\hline \multirow[t]{2}{*}{ Sample ID } & \multirow[t]{2}{*}{ Unit } & \multirow{2}{*}{$\begin{array}{l}\text { Depth } \\
(\mathrm{m})\end{array}$} & \multirow{2}{*}{$\begin{array}{c}\mathrm{Al}_{2} \mathrm{O}_{3}{ }^{\#} \\
(\%)\end{array}$} & \multirow{2}{*}{$\begin{array}{l}\mathrm{TiO}_{2} \\
(\%)\end{array}$} & \multirow{2}{*}{$\begin{array}{c}\mathrm{Nb} \\
(\mathrm{mg} / \mathrm{kg})\end{array}$} & \multirow{2}{*}{$\begin{array}{c}\mathrm{La} \\
(\mathrm{mg} / \mathrm{kg})\end{array}$} & \multirow{2}{*}{$\begin{array}{c}\mathrm{Sm} \\
(\mathrm{mg} / \mathrm{kg})\end{array}$} & \multirow{2}{*}{$\begin{array}{c}\mathrm{Li} \\
(\mathrm{mg} / \mathrm{kg})\end{array}$} & \multirow[t]{2}{*}{$\delta^{7} \mathrm{Li}$} & \multirow{2}{*}{$\begin{array}{c} \pm \\
(\%)\end{array}$} & \multirow[t]{2}{*}{$2 \mathrm{SD}$} & \multicolumn{5}{|c|}{ Extracted Li } & \multicolumn{5}{|c|}{ Extracted Li } \\
\hline & & & & & & & & & & & & $\mathrm{W}$ & $\mathrm{E}$ & $\begin{array}{c}\mathrm{C} \\
\mathrm{mg} / \mathrm{kg}\end{array}$ & $\mathrm{O}$ & $\mathrm{R}$ & $\mathrm{W}$ & $E$ & $\begin{array}{c}\mathrm{C} \\
(\%)\end{array}$ & $\mathrm{O}$ & $\mathrm{R}$ \\
\hline \multicolumn{22}{|c|}{$\underline{\text { Greene County, PA, USA }}$} \\
\hline G1 & Marcellus shale* & 2374 & 13.7 & 0.39 & 11.8 & 39.9 & 14 & 42 & 0.5 & \pm & 0.1 & 0.53 & 0.47 & 0.79 & 7.45 & 32.6 & 1.3 & 1.1 & 1.9 & 18 & 78 \\
\hline $\mathrm{G} 2$ & Marcellus Limestone ${ }^{\dagger}$ & 2376 & 2.97 & 0.07 & 2.40 & 11.5 & 5.8 & 13 & -0.8 & \pm & 0.2 & 0.16 & 0.16 & 0.84 & 1.88 & 9.49 & 1.3 & 1.3 & 6.7 & 15 & 76 \\
\hline G3 & Marcellus shale & 2380 & 15.8 & 0.35 & 11.0 & 45.7 & 11 & 44 & 0.7 & \pm & 0.1 & 0.88 & 0.50 & 0.73 & 6.66 & 35.3 & 2.0 & 1.1 & 1.6 & 15 & 80 \\
\hline G4 & Marcellus shale & 2386 & 17.1 & 0.47 & 14.0 & 44.7 & 7.5 & 47 & 2.1 & \pm & 0.1 & 1.30 & 0.51 & 0.56 & 9.50 & 35.6 & 2.7 & 1.1 & 1.2 & 20 & 75 \\
\hline G5 & Marcellus shale & 2389 & 17.7 & 0.45 & 13.5 & 42.8 & 7.1 & 48 & 1.9 & \pm & 0.1 & 1.38 & 0.50 & 0.44 & 9.04 & 36.2 & 2.9 & 1.0 & 0.9 & 19 & 76 \\
\hline G6 & Marcellus shale & 2398 & 15.0 & 0.44 & 13.8 & 41.6 & 9.2 & 36 & 4.3 & \pm & 0.4 & 1.46 & 0.40 & 0.59 & 0.71 & 32.7 & 4.1 & 1.1 & 1.7 & 2.0 & 91 \\
\hline G7 & Onondaga limestone & 2404 & 2.57 & 0.06 & 2.40 & 41.5 & 8.5 & 21 & 13.3 & \pm & 0.2 & 0.30 & 0.16 & 0.80 & 0.27 & 19.2 & 1.4 & 0.8 & 3.9 & 1.3 & 93 \\
\hline G8 & Onondaga limestone & 2407 & 0.45 & ND & ND & ND & ND & 7.0 & 15.0 & \pm & 0.3 & 0.11 & 0.03 & 0.45 & 0.04 & 6.39 & 1.5 & 0.4 & 6.4 & 0.6 & 91 \\
\hline \multicolumn{22}{|c|}{ Tioga County, NY, USA } \\
\hline $\mathrm{T} 1$ & Tully limestone & 901 & 7.92 & 0.26 & 7.20 & 24.7 & 4.0 & 38 & -0.9 & \pm & 0.1 & 0.38 & 0.27 & 0.69 & 2.00 & 34.7 & 1.0 & 0.7 & 1.8 & 5.3 & 91 \\
\hline $\mathrm{T} 2$ & Marcellus shale & 1337 & 17.3 & 0.51 & 15.8 & 50.7 & 8.9 & 85 & -2.3 & \pm & 0.3 & 1.09 & 0.74 & 0.98 & 9.60 & 73.1 & 1.3 & 0.9 & 1.1 & 11 & 85 \\
\hline $\mathrm{T} 3$ & Marcellus shale & 1358 & 15.9 & 0.42 & 10.8 & 44.8 & 8.1 & 61 & -0.8 & \pm & 0.3 & 1.63 & 0.60 & 0.38 & 8.52 & 49.9 & 2.7 & 1.0 & 0.6 & 14 & 82 \\
\hline $\mathrm{T} 4$ & Marcellus shale & 1370 & 12.9 & 0.35 & 9.70 & 39.4 & 7.3 & 25 & 2.9 & \pm & 0.2 & 2.01 & 0.45 & 0.34 & 0.50 & 21.5 & 8.1 & 1.8 & 1.4 & 2.0 & 87 \\
\hline $\mathrm{T} 5$ & Marcellus shale* & 1389 & 6.54 & 0.18 & 4.60 & 28.0 & 6.2 & 19 & 3.2 & \pm & 0.3 & 1.51 & 0.41 & 0.36 & 3.60 & 12.7 & 8.1 & 2.2 & 1.9 & 19 & 68 \\
\hline T6 & Onondaga limestone & 1410 & 8.24 & 0.27 & 8.80 & 29.6 & 5.5 & 34 & 4.7 & \pm & 0.1 & 2.92 & 1.39 & 1.05 & 1.56 & 27.3 & 8.5 & 4.1 & 3.1 & 4.5 & 80 \\
\hline $\mathrm{T} 7$ & Oriskany sandstone & 1434 & 3.38 & 0.14 & 7.30 & 23.1 & 4.1 & 17 & 4.6 & \pm & 0.3 & 0.48 & 0.42 & 0.68 & 1.29 & 13.8 & 2.9 & 2.5 & 4.1 & 7.7 & 83 \\
\hline
\end{tabular}

*Calcareous shale

Limestone lenses within the Marcellus Formation

\#previously reported in Phan et al., (2015) 
Table 3 Concentrations of sodium and lithium and lithium isotopic compositions of produced water samples from oil and gas wells in southwestern and north central Pennsylvania.

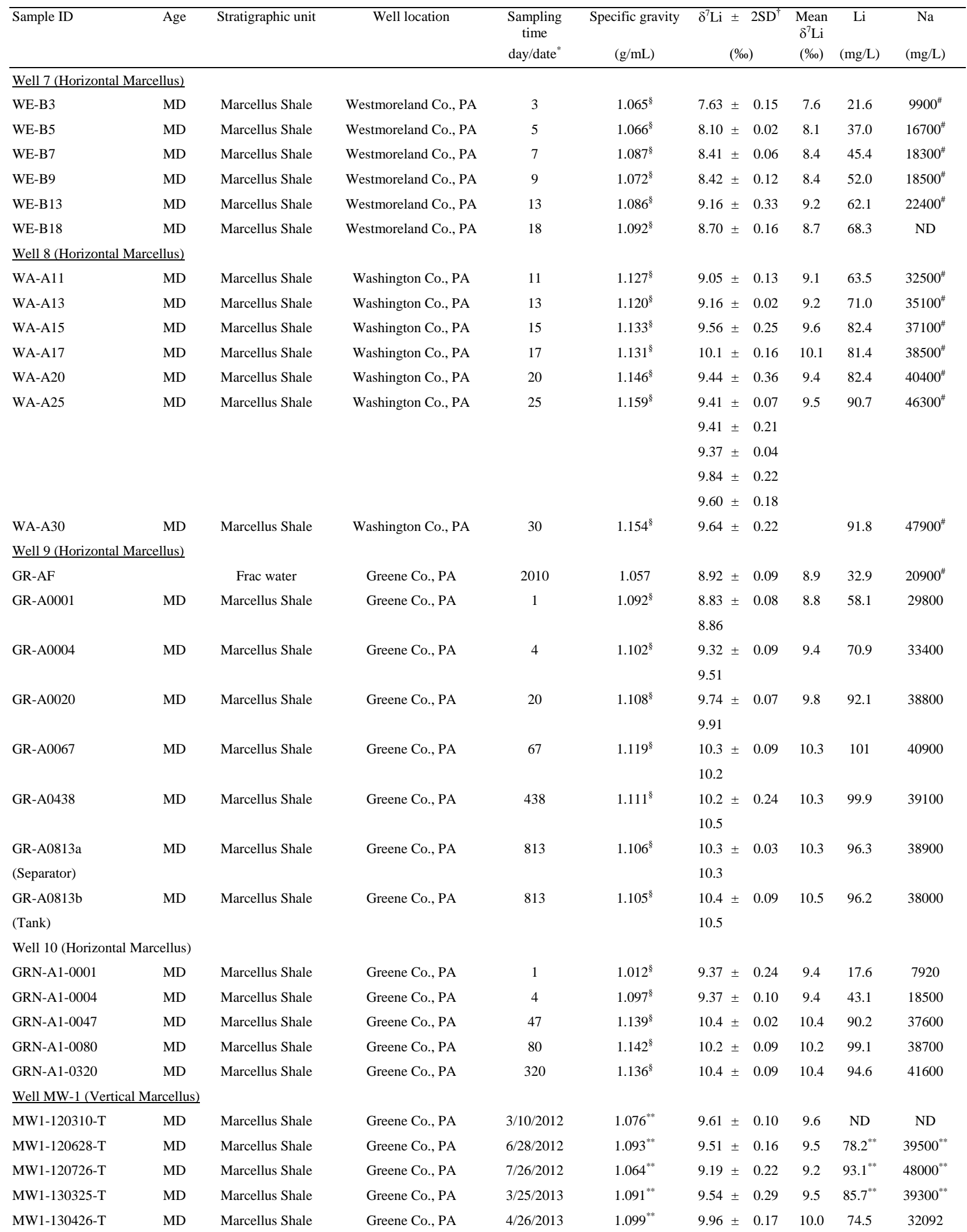




\begin{tabular}{|c|c|c|c|c|c|c|c|c|c|c|}
\hline MW1-130626-T & MD & Marcellus Shale & Greene Co., PA & $6 / 26 / 2013$ & $1.095^{* * *}$ & $9.81 \pm$ & 0.27 & 9.8 & $89.0^{* *}$ & $40700^{* *}$ \\
\hline \multicolumn{11}{|l|}{ Well UD-2 } \\
\hline UD2-120310-S & UD/LM & Multiple units & Greene Co., PA & 03/10/2012 & $1.096^{* * *}$ & $13.7 \pm$ & 0.12 & 13.7 & $23.0^{* * *}$ & $35400^{* *}$ \\
\hline UD2-120518-S & UD/LM & Multiple units & Greene Co., PA & 05/18/2012 & $1.100^{* *}$ & $14.9 \pm$ & 0.06 & 14.9 & $20.2^{* * *}$ & $33200^{* *}$ \\
\hline UD2-120628-S & UD/LM & Multiple units & Greene Co., PA & 06/28/2012 & $1.101^{* *}$ & $15.2 \pm$ & 0.29 & 15.2 & $21.8^{* *}$ & $36300^{* *}$ \\
\hline UD2-120726-S & $\mathrm{UD} / \mathrm{LM}$ & Multiple units & Greene Co., PA & $07 / 26 / 2012$ & $1.099^{* * *}$ & $16.5 \pm$ & 0.13 & 16.5 & $24.6^{* *}$ & $37500^{* * *}$ \\
\hline UD2-120726-T & UD/LM & Multiple units & Greene Co., PA & $07 / 26 / 2012$ & $1.110^{* *}$ & $13.9 \pm$ & 0.09 & 13.9 & $22.9^{* * *}$ & $36500^{* *}$ \\
\hline UD2-120829-S & UD/LM & Multiple units & Greene Co., PA & 08/29/2012 & $1.100^{* * *}$ & $14.9 \pm$ & 0.14 & 14.9 & $30.3^{* *}$ & $44100^{* *}$ \\
\hline UD2-120928-S & UD/LM & Multiple units & Greene Co., PA & 09/28/2012 & $1.099^{* * *}$ & $14.4 \pm$ & 0.05 & 14.4 & $26.0^{* * *}$ & $39900^{* *}$ \\
\hline UD2-121025-S & $\mathrm{UD} / \mathrm{LM}$ & Multiple units & Greene Co., PA & $10 / 25 / 2012$ & $1.115^{* * *}$ & $14.1 \pm$ & 0.02 & 14.1 & $29.1^{* * *}$ & $43400^{* *}$ \\
\hline UD2-121213-S & UD/LM & Multiple units & Greene Co., PA & $12 / 13 / 2012$ & $1.068^{* *}$ & $15.4 \pm$ & 0.01 & 15.4 & $26.4^{* * *}$ & $40400^{* *}$ \\
\hline UD2-130426-S & $\mathrm{UD} / \mathrm{LM}$ & Multiple units & Greene Co., PA & $04 / 26 / 2013$ & $1.096^{* * *}$ & $14.7 \pm$ & 0.03 & 14.7 & $26.5^{* *}$ & $40300^{* *}$ \\
\hline UD2-130626-S & $\mathrm{UD} / \mathrm{LM}$ & Multiple units & Greene Co., PA & $06 / 26 / 2013$ & $1.099^{* * *}$ & $14.1 \pm$ & 0.24 & 14.1 & $26.0^{* * *}$ & $38900^{* *}$ \\
\hline UD2-130807-S & $\mathrm{UD} / \mathrm{LM}$ & Multiple units & Greene Co., PA & 08/07/2013 & $1.093^{* * *}$ & $14.1 \pm$ & 0.30 & 14.1 & $26.2^{* *}$ & $40600^{* *}$ \\
\hline \multicolumn{11}{|l|}{$\underline{\text { Well UD-5 }}$} \\
\hline UD5-120310-S & UD/LM & Multiple units & Greene Co., PA & 03/10/2012 & $1.085^{* *}$ & $15.3 \pm$ & 0.21 & 15.3 & ND & $37300^{* *}$ \\
\hline UD5-120310-T & $\mathrm{UD} / \mathrm{LM}$ & Multiple units & Greene Co., PA & 03/10/2012 & $1.110^{* * *}$ & $14.5 \pm$ & 0.04 & 14.5 & ND & $38800^{* *}$ \\
\hline UD5-120518-S & UD/LM & Multiple units & Greene Co., PA & 05/18/2012 & $1.117^{* *}$ & $15.2 \pm$ & 0.18 & 15.2 & $19.7^{* *}$ & $3900^{* *}$ \\
\hline UD5-120726-S & $\mathrm{UD} / \mathrm{LM}$ & Multiple units & Greene Co., PA & 07/26/2012 & $1.084^{* * *}$ & $14.8 \pm$ & 0.24 & 14.8 & $23.1^{* *}$ & $42600^{* *}$ \\
\hline UD5-120829-S & $\mathrm{UD} / \mathrm{LM}$ & Multiple units & Greene Co., PA & 08/29/2012 & $1.111^{* * *}$ & $14.4 \pm$ & 0.09 & 14.4 & $21.1^{* *}$ & $40100^{* *}$ \\
\hline UD5-120928-S & $\mathrm{UD} / \mathrm{LM}$ & Multiple units & Greene Co., PA & $09 / 28 / 2012$ & $1.074^{* *}$ & $14.3 \pm$ & 0.20 & 14.3 & $21.7^{* *}$ & $40600^{* *}$ \\
\hline UD5-120928-T & $\mathrm{UD} / \mathrm{LM}$ & Multiple units & Greene Co., PA & 09/28/2012 & $1.087^{* *}$ & $15.0 \pm$ & 0.03 & 15.0 & $19.1^{* *}$ & $37100^{* *}$ \\
\hline UD5-130325-S & $\mathrm{UD} / \mathrm{LM}$ & Multiple units & Greene Co., PA & $03 / 25 / 2013$ & $1.059^{* *}$ & $14.3 \pm$ & 0.01 & 14.3 & $18.4^{* *}$ & $36100^{* *}$ \\
\hline UD5-130708-S & $\mathrm{UD} / \mathrm{LM}$ & Multiple units & Greene Co., PA & 08/07/2013 & $1.103^{* *}$ & $14.3 \pm$ & 0.35 & 14.3 & $20.1^{* *}$ & $38600^{* *}$ \\
\hline \multicolumn{11}{|l|}{ Well UD-6 } \\
\hline UD6-120310-S & UD/LM & Multiple units & Greene Co., PA & 03/10/2012 & $1.097^{* * *}$ & 14.4 & & 14.4 & $26.4^{* * *}$ & $40600^{* *}$ \\
\hline UD6-120518-S & $\mathrm{UD} / \mathrm{LM}$ & Multiple units & Greene Co., PA & $05 / 18 / 2012$ & $1.108^{* *}$ & 14.4 & & 14.5 & 25.3 & 45396 \\
\hline & & & & & & $14.6 \pm$ & 0.26 & & & \\
\hline UD6-120628-S & $\mathrm{UD} / \mathrm{LM}$ & Multiple units & Greene Co., PA & $06 / 28 / 2012$ & $1.110^{* * *}$ & $14.1 \pm$ & 0.05 & 14.3 & 25.5 & $40400^{* *}$ \\
\hline UD6-120726-S & UD/LM & Multiple units & Greene Co., PA & $07 / 26 / 2012$ & $1.074^{* *}$ & $14.1 \pm$ & 0.24 & 14.1 & $26.9^{* * *}$ & $40800^{* *}$ \\
\hline \multicolumn{11}{|l|}{$\underline{\text { Grab samples }}$} \\
\hline \multirow[t]{2}{*}{ ST46 } & UD/LM & Burket Shale & Tioga Co., PA & $09 / 25 / 2012$ & ND & $16.6 \pm$ & 0.27 & 16.5 & $103^{\dagger \dagger}$ & $47100^{\dagger \dagger}$ \\
\hline & & & & & & $16.5 \pm$ & 0.18 & & & \\
\hline \multirow[t]{2}{*}{$\mathrm{CO} 12$} & MD & Marcellus Formation & Tioga Co., PA & $09 / 24 / 2012$ & ND & $14.1 \pm$ & 0.10 & 14.3 & $208^{\dagger \dagger}$ & $52800^{\dagger \dagger}$ \\
\hline & & & & & & 14.5 & & & & \\
\hline \multirow[t]{2}{*}{ SA14 } & MD & Marcellus Formation & Tioga Co., PA & $09 / 24 / 2012$ & ND & $14.8 \pm$ & 0.02 & 15.0 & $233^{\dagger \dagger}$ & $63100^{\dagger \dagger}$ \\
\hline & & & & & & $15.2 \pm$ & 0.18 & & & \\
\hline \multirow[t]{3}{*}{ SILN-LP } & $\mathrm{U}-\mathrm{SN}$ & Lockport Dolomite & ND & ND & 1.126 & $19.3 \pm$ & 0.39 & 19.2 & 20.8 & 41600 \\
\hline & & & & & & $19.0 \pm$ & 0.35 & & & \\
\hline & & & & & & $19.3 \pm$ & 0.40 & & & \\
\hline \multirow[t]{2}{*}{ SILN-ND } & M-SN & Newburg Sandstone & ND & ND & 1.133 & $15.3 \pm$ & 0.07 & 15.1 & 154 & 69500 \\
\hline & & & & & & $14.8 \pm$ & 0.11 & & & \\
\hline \multicolumn{11}{|c|}{ Note: UD: Upper Devonian; LM: Lower Mississippian; MD: Middle Devonian; U-SN: Upper Silurian; M-SN: Middle Silurian; Col. Rep.=Column replicate } \\
\hline \multicolumn{11}{|c|}{ "Sampling time of Marcellus Fm. samples reported as numbe } \\
\hline \multicolumn{11}{|c|}{$\begin{array}{l}{ }^{\dagger} \text { Two standard deviations of at least } 2 \text { non-consecutive meast } \\
\text { replicates } \\
{ }^{\S} \text { Specific gravities previously reported in Phan et al. (2015) }\end{array}$} \\
\hline \multicolumn{11}{|c|}{ \# Previously reported in Chapman et al. (2012). Numbers are round up to 3 significant figures } \\
\hline \multicolumn{11}{|c|}{${ }^{* * *}$ Previously reported in Kolesar Kohl et al. (2014) } \\
\hline${ }^{\dagger}$ Concentrations & id $\mathrm{Na}$ of & samples that were pre & reported in Rov & ., (2015) & & & & & & \\
\hline
\end{tabular}


Table 4 Strontium isotopes of produced water.

\begin{tabular}{|c|c|c|c|c|c|}
\hline Sample ID & Type & ${ }^{87} \mathrm{Sr} /{ }^{86} \mathrm{Sr}^{*}$ & \pm & $2 \mathrm{SD}^{\dagger}$ & Data Source \\
\hline \multicolumn{6}{|c|}{ Well 7 (Horizontal Marcellus) } \\
\hline WE-B3 & MD brine & 0.712076 & \pm & 0.000007 & (Chapman et al., 2012) \\
\hline WE-B5 & MD brine & 0.712108 & \pm & 0.000011 & (Chapman et al., 2012) \\
\hline WE-B7 & MD brine & 0.712088 & \pm & 0.000007 & (Chapman et al., 2012) \\
\hline WE-B9 & MD brine & 0.712108 & \pm & 0.000008 & (Chapman et al., 2012) \\
\hline WE-B13 & MD brine & 0.712117 & \pm & 0.000009 & (Chapman et al., 2012) \\
\hline WE-B18 & MD brine & 0.712113 & \pm & 0.000009 & (Chapman et al., 2012) \\
\hline \multicolumn{6}{|c|}{ Well 8 (Horizontal Marcellus) } \\
\hline WA-A11 & MD brine & 0.711129 & \pm & 0.000008 & (Chapman et al., 2012) \\
\hline WA-A13 & MD brine & 0.710988 & \pm & 0.000010 & (Chapman et al., 2012) \\
\hline WA-A15 & MD brine & N.D. ${ }^{8}$ & & & (Chapman et al., 2012) \\
\hline WA-A17 & MD brine & 0.711056 & \pm & 0.000011 & (Chapman et al., 2012) \\
\hline WA-A20 & MD brine & 0.711088 & \pm & 0.000009 & (Chapman et al., 2012) \\
\hline WA-A25 & MD brine & 0.711021 & \pm & 0.000010 & (Chapman et al., 2012) \\
\hline WA-A30 & MD brine & 0.711076 & \pm & 0.000008 & (Chapman et al., 2012) \\
\hline \multicolumn{6}{|c|}{ Well 9 (Horizontal Marcellus) } \\
\hline GR-AF & Frac water of Well 9 & 0.710084 & \pm & 0.000008 & (Chapman et al., 2012) \\
\hline GR-A0001 & MD brine & 0.710988 & \pm & 0.000008 & (Chapman et al., 2012) \\
\hline GR-A0004 & MD brine & 0.710961 & \pm & 0.000009 & (Chapman et al., 2012) \\
\hline GR-A0020 & MD brine & 0.711173 & \pm & 0.000009 & (Chapman et al., 2012) \\
\hline$(\text { Replicate })^{\#}$ & MD brine & 0.711191 & \pm & 0.000011 & This study \\
\hline GR-A0067 & MD brine & 0.711261 & \pm & 0.000008 & (Capo et al., 2014) \\
\hline GR-A0438 & MD brine & 0.711394 & \pm & 0.000008 & (Capo et al., 2014) \\
\hline GR-A0813a (Separator) & MD brine & 0.711417 & \pm & 0.000010 & (Capo et al., 2014) \\
\hline (Replicate) & & 0.711422 & \pm & 0.000010 & This study \\
\hline GR-A0813b (Tank) & MD brine & 0.711412 & \pm & 0.000010 & (Capo et al., 2014) \\
\hline \multicolumn{6}{|c|}{$\underline{\text { Well } 10 \text { (Horizontal Marcellus) }}$} \\
\hline GRN-A1-0001 & MD brine & 0.710785 & \pm & 0.000010 & (Capo et al., 2014) \\
\hline GRN-A1-0004 & MD brine & 0.711149 & \pm & 0.000008 & (Capo et al., 2014) \\
\hline GRN-A1-0047 & MD brine & 0.711246 & \pm & 0.000010 & (Capo et al., 2014) \\
\hline GRN-A1-0080 & MD brine & 0.711267 & \pm & 0.000008 & (Capo et al., 2014) \\
\hline (Replicate) & & 0.711269 & \pm & 0.000012 & This study \\
\hline GRN-A1-0320 & MD brine & 0.711378 & \pm & 0.000008 & (Kolesar Kohl et al., 2014) \\
\hline \multicolumn{6}{|c|}{ Well MW-1 (Vertical Marcellus) } \\
\hline MW1-120310-T & MD brine & 0.711580 & \pm & 0.000006 & (Kolesar Kohl et al., 2014) \\
\hline MW1-120628-T & MD brine & 0.711726 & \pm & 0.000006 & (Kolesar Kohl et al., 2014) \\
\hline MW1-120726-T & MD brine & 0.711710 & \pm & 0.000008 & (Kolesar Kohl et al., 2014) \\
\hline MW1-130325-T & MD brine & 0.711703 & \pm & 0.000007 & (Kolesar Kohl et al., 2014) \\
\hline MW1-130426-T & MD brine & 0.711710 & \pm & 0.000007 & (Kolesar Kohl et al., 2014) \\
\hline MW1-130626-T & MD brine & 0.711692 & \pm & 0.000008 & (Kolesar Kohl et al., 2014) \\
\hline \multicolumn{6}{|l|}{$\underline{\text { Well UD-2 }}$} \\
\hline UD2-120310-S & UD brine & 0.719976 & \pm & 0.000013 & (Kolesar Kohl et al., 2014) \\
\hline UD2-120518-S & UD brine & 0.720076 & \pm & 0.000016 & (Kolesar Kohl et al., 2014) \\
\hline UD2-120628-S & UD brine & 0.720057 & \pm & 0.000007 & (Kolesar Kohl et al., 2014) \\
\hline UD2-120726-S & UD brine & 0.719873 & \pm & 0.000009 & (Kolesar Kohl et al., 2014) \\
\hline UD2-120726-T & UD brine & 0.719955 & \pm & 0.000008 & (Kolesar Kohl et al., 2014) \\
\hline UD2-120829-S & UD brine & 0.719933 & \pm & 0.000006 & (Kolesar Kohl et al., 2014) \\
\hline UD2-120928-S & UD brine & 0.719932 & \pm & 0.000006 & (Kolesar Kohl et al., 2014) \\
\hline UD2-121025-S & UD brine & 0.720018 & \pm & 0.000010 & (Kolesar Kohl et al., 2014) \\
\hline
\end{tabular}




\begin{tabular}{|c|c|c|c|c|c|}
\hline UD2-121213-S & UD brine & 0.719909 & \pm & 0.000010 & (Kolesar Kohl et al., 2014) \\
\hline UD2-130426-S & UD brine & 0.720026 & \pm & 0.000010 & (Kolesar Kohl et al., 2014) \\
\hline UD2-130626-S & UD brine & 0.720084 & \pm & 0.000011 & (Kolesar Kohl et al., 2014) \\
\hline UD2-130807-S & UD brine & 0.719976 & \pm & 0.000013 & (Kolesar Kohl et al., 2014) \\
\hline \multicolumn{6}{|l|}{$\underline{\text { Well UD-5 }}$} \\
\hline UD5-120310-S & UD brine & 0.720949 & \pm & 0.000011 & (Kolesar Kohl et al., 2014) \\
\hline UD5-120310-T & UD brine & 0.720921 & \pm & 0.000013 & (Kolesar Kohl et al., 2014) \\
\hline UD5-120518-S & UD brine & 0.720853 & \pm & 0.000013 & (Kolesar Kohl et al., 2014) \\
\hline UD5-120726-S & UD brine & 0.720934 & \pm & 0.000008 & (Kolesar Kohl et al., 2014) \\
\hline UD5-120829-S & UD brine & 0.720950 & \pm & 0.000006 & (Kolesar Kohl et al., 2014) \\
\hline UD5-120928-S & UD brine & 0.720955 & \pm & 0.000007 & (Kolesar Kohl et al., 2014) \\
\hline UD5-120928-T & UD brine & 0.720945 & \pm & 0.000006 & (Kolesar Kohl et al., 2014) \\
\hline UD5-130325-S & UD brine & 0.720960 & \pm & 0.000015 & (Kolesar Kohl et al., 2014) \\
\hline UD5-130708-S & UD brine & 0.720820 & \pm & 0.000011 & (Kolesar Kohl et al., 2014) \\
\hline \multicolumn{6}{|l|}{ Well UD-6 } \\
\hline UD6-120310-S & UD brine & 0.720033 & \pm & 0.000014 & (Kolesar Kohl et al., 2014) \\
\hline UD6-120518-S & UD brine & 0.719918 & \pm & 0.000014 & (Kolesar Kohl et al., 2014) \\
\hline (Replicate) & & 0.719944 & \pm & 0.000015 & (Kolesar Kohl et al., 2014) \\
\hline (Replicate) & & 0.719951 & \pm & 0.000020 & (Kolesar Kohl et al., 2014) \\
\hline (Replicate) & & 0.719969 & \pm & 0.000016 & (Kolesar Kohl et al., 2014) \\
\hline (Replicate) & & 0.719966 & \pm & 0.000018 & (Kolesar Kohl et al., 2014) \\
\hline (Replicate) & & 0.719977 & \pm & 0.000015 & (Kolesar Kohl et al., 2014) \\
\hline (Replicate) & & 0.719970 & \pm & 0.000012 & This study \\
\hline UD6-120628-S & UD brine & 0.720032 & \pm & 0.000006 & (Kolesar Kohl et al., 2014) \\
\hline UD6-120726-S & UD brine & 0.719770 & \pm & 0.000006 & (Kolesar Kohl et al., 2014) \\
\hline \multicolumn{6}{|l|}{ Grab samples } \\
\hline ST46 & UD brine & 0.710630 & \pm & 0.000010 & This study \\
\hline (Replicate) & & 0.710647 & \pm & N.A. & This study \\
\hline $\mathrm{CO} 12$ & MD brine & 0.709983 & \pm & 0.000014 & This study \\
\hline (Replicate) & & 0.709990 & \pm & N.A. & This study \\
\hline SA14 & MD brine & 0.709423 & \pm & N.A. & This study \\
\hline SILN-LP & U-SN brine & 0.712216 & \pm & 0.000011 & This study \\
\hline (Replicate) & & 0.712219 & \pm & 0.000010 & This study \\
\hline SILN-ND & M-SN brine & 0.709555 & \pm & 0.000011 & This study \\
\hline (Replicate) & & 0.709554 & \pm & 0.000007 & This study \\
\hline \multicolumn{6}{|c|}{ Note: MD: Middle Devonian; UD: Upper Devonian;U-SN: Upper Silurian; M-SN: Middle Silurian } \\
\hline \multicolumn{6}{|c|}{${ }^{*}$ Normalized to SRM $987 \mathrm{Sr}$ standard $=0.710240$} \\
\hline \multicolumn{6}{|c|}{${ }^{\dagger}$ Two standard errors based on in run measurement } \\
\hline \multicolumn{6}{|c|}{${ }^{\S}$ N.D. $=$ not determined } \\
\hline \multicolumn{6}{|c|}{$\begin{array}{l}{ }^{\#} \text { Reported }{ }^{87} \mathrm{Sr} /{ }^{86} \mathrm{Sr} \text { for sample replicate was based on measurement of a second aliquot of the sample that was separately } \\
\text { processed through column }\end{array}$} \\
\hline
\end{tabular}




\section{FIGURE CAPTIONS}

Fig. 1. Map showing part of North America Middle Devonian paleogeography modified after Blakey (2013). AH = Acadian Highlands. Inset shows the extent of the Middle Devonian Marcellus Shale in the present-day Appalachian Basin. Produced water samples are from Greene Co., (A), Washington Co. (B), Westmoreland Co. (C), Tioga Co., PA (D). Core samples are from Greene Co, PA (blue circle); and dry-drilled rock cuttings from Tioga Co., NY (blue square). Base map is modified after Whitacre, 2014.

Fig. 2. Lithium separation procedure developed in this study.

Fig. 3. Comparison of our measured $\delta^{7} \mathrm{Li}$ values and reported $\delta^{7} \mathrm{Li}$ values of reference samples analyzed during this study.

Fig. 4. (a) Li concentration and (b) $\delta^{7} \mathrm{Li}$ vs. total dissolved solid (TDS) of Marcellus produced waters in southwestern PA (time series) and north-central PA (grab samples from multiple wells). Solid and dashed lines are best fit lines and 95\% of confidence lines, respectively. TDS data are from Chapman et al. (2012) and Rowan et al. (2015).

Fig. 5. Post-hydraulic fracturing temporal variation in (a) Li concentration (b) $\delta^{7} \mathrm{Li}$ and (c) $\mathrm{Li}^{*} 1000 / \mathrm{Na}$ in produced water from four hydraulically fractured horizontal Marcellus Shale gas wells. [Li] and $\delta^{7} \mathrm{Li}$ of the produced waters reach steady state values by day 45 . Frac water from Well 9, and produced water from MW1, a vertical Marcellus well in Greene County, PA are shown for comparison. Well MW1 has been in production since 2008 . Error bars $(2 \sigma)$ of $\delta^{7} \mathrm{Li}$ are two standard deviations of at least two non-consecutive measurements.

Fig. 6. The distribution of $\mathrm{Li}$ based on sequential extractions, $\mathrm{Li} / \mathrm{Al}_{2} \mathrm{O}_{3}$, and whole rock lithium isotopic composition of Middle Devonian Marcellus Shale and associated lithologies from drill cuttings and core samples from the northeastern (NY) and southwestern (PA) Appalachian Basin.

Fig. 7. Variations in Li concentrations with immobile elements in Marcellus shale rocks follow the same pattern for (a) $\mathrm{Al}_{2} \mathrm{O}_{3}$, (b) $\mathrm{TiO}_{2}$ and (c) $\mathrm{Nb}$. Dashed lines are best-fit lines for data from NY site only. Plots $\delta^{7} \mathrm{Li}$ vs. (d) $\mathrm{La} / \mathrm{Sm}$ and (e) $\mathrm{TiO}_{2} / \mathrm{Al}_{2} \mathrm{O}_{3}$ plausibly suggest the potential contribution of volcanogenic components in Marcellus shale rocks. Shaded bars show ranges of $\mathrm{La} / \mathrm{Sm}$ and $\mathrm{TiO}_{2} / \mathrm{Al}_{2} \mathrm{O}_{3}$ of volcanic rocks (andesite, rhyodacite, dacite) (Blatter and Carmichael, 1998; Bryant et al., 2006). Plot (f) shows that clay minerals enriched in isotopically light Li are the main sinks of $\mathrm{Li}$ in Marcellus Shale. Solid line is best fit line for data from both sites. $\mathrm{Al}_{2} \mathrm{O}_{3}$ data previously reported in Phan et al., (2015). Average upper continental crust values (crossed square; Rudnick and Gao, 2003) are plotted for comparison. Symbols are the same as in Fig. 6.

Fig. 8. Whole rock lithium concentrations correlate with $\mathrm{Al}_{2} \mathrm{O}_{3} / \mathrm{SiO}_{2}$ (a) in samples from this study $\left(\mathrm{Al}_{2} \mathrm{O}_{3}\right.$ and $\mathrm{SiO}_{2}$ were previously reported in Phan et al., 2015). Negative correlation of whole rock [Li] and $\delta^{7} \mathrm{Li}(\mathrm{b})$ suggests ${ }^{6} \mathrm{Li}$ is preferentially incorporated into the structure of clay minerals. The negligible amount of exchangeable compared to structural $\mathrm{Li}(\mathrm{c})$ is in agreement 
with the poor exchange affinity of Li; it can be replaced from exchange sites by any competing cations in the fluid (Starkey, 1982). Symbols are the same as in Fig. 6.

Fig. 9. Data from this study and compiled from previous work (Chapman et al., 2012; Hayes, 2009; Rowan et al., 2015; Warner et al., 2014) showing the variation in $\mathrm{Li} / \mathrm{Cl} \mathrm{vs}$. $\mathrm{Br} / \mathrm{Cl}$ of Silurian - Devonian formation waters. Note that all formation waters of the Appalachian Basin plot within the range of brines with an evaporated seawater origin and very distinct from halite dissolution brines (defined by Bagheri et al., 2014), and are enriched in Li relative to the modern seawater evaporation trend (McCaffrey et al., 1987).

Fig. 10. Calculated Li concentrations in clay are explained by the Li concentrations in the fluid during clay formation (Decarreau et al., 2012). Ranges of estimated Li concentration in illite and measured Li concentrations in the Marcellus formation waters from southwestern PA (rectangle, solid red line) and from north central PA (rectangle, dashed black line) are consistent with authigenic clay formation at temperatures $<120{ }^{\circ} \mathrm{C}$.

Fig. 11. $\delta^{7} \mathrm{Li}$ vs. Li concentration (a) and $\delta^{7} \mathrm{Li}$ vs. ${ }^{87} \mathrm{Sr} /{ }^{86} \mathrm{Sr}$ (b) in Upper Devonian, Middle Devonian (Marcellus Shale), and Silurian formation waters of Appalachian Basin. Hypothetical mixing line (solid line) shows that lithium isotopes of Upper Devonian brine can be potentially used as early indication of upward migration of Middle Devonian formation water. In Greene County, PA, distinct Li and $\mathrm{Sr}$ isotopic compositions of Upper Devonian and Middle Devonian brines implies the presence of hydrologic separation in the study area. Two conservative mixing lines show that accidental release of Upper Devonian (dotted line) and Middle Devonian (dashed line) brines into stream water (Kolesar Kohl et al., 2014) can be locally distinguished using Li and $\mathrm{Sr}$ isotopes. The ${ }^{87} \mathrm{Sr} /{ }^{86} \mathrm{Sr}$ values for formation water in Greene County, PA are from Chapman et al. (2012), Capo et al. (2014), and (Kolesar Kohl et al., 2014). Li data of Silurian formation water are compiled from this study and previous works (Warner et al., 2012; Warner et al., 2014). 
Figure 1
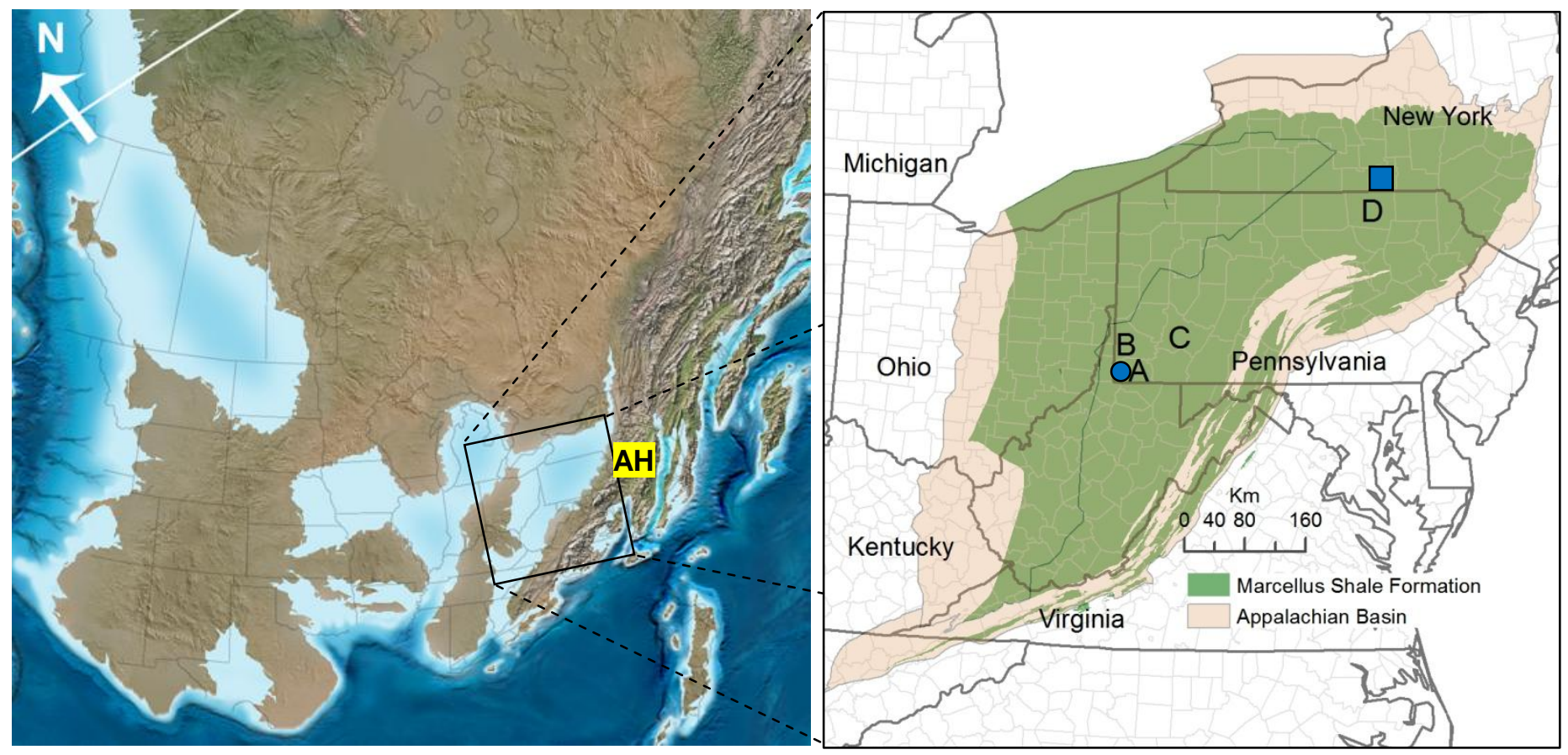
Pack 2.0 mL AG50W-X8 (200-400

mesh) resin in a Poly-Prep column

Wash with $10 \mathrm{~mL} 2 \% \mathrm{HNO}_{3}$, and then $10 \mathrm{~mL} 6 \mathrm{~N} \mathrm{HCl}$

Condition with $10 \mathrm{~mL} 1.50 \mathrm{~N}$ $\mathrm{HNO}_{3}: 70 \% \mathrm{CH}_{3} \mathrm{OH}$

Wash with $10 \mathrm{~mL} 18.2 \mathrm{M} \Omega \mathrm{cm}$ water

Condition with $5 \mathrm{~mL} 1.50 \mathrm{~N}$ $\mathrm{HNO}_{3}: 70 \% \mathrm{CH}_{3} \mathrm{OH}$. Collect for pre-column check for $\mathrm{Li}$

Load $0.5 \mathrm{~mL}$ sample in $1.0 \mathrm{~N}$ $\mathrm{HNO}_{3}$, add drop wise $0.5 \mathrm{~mL} 1.50$ $\mathrm{N} \mathrm{HNO}_{3}: 70 \% \mathrm{CH}_{3} \mathrm{OH}$ to "push" down sample.

Collect Li fraction with $18.7 \mathrm{~mL}$ $1.50 \mathrm{~N} \mathrm{HNO}_{3}: 70 \% \mathrm{CH}_{3} \mathrm{OH}$. Dry down. Redissolve in $2 \% \mathrm{HNO}_{3}$ prior to isotopic measurement

Pass $2 \mathrm{~mL}(1 \mathrm{cv}) 1.50 \mathrm{~N}$ $\mathrm{HNO}_{3}: 70 \% \mathrm{CH}_{3} \mathrm{OH}$. Collect for post-column check 


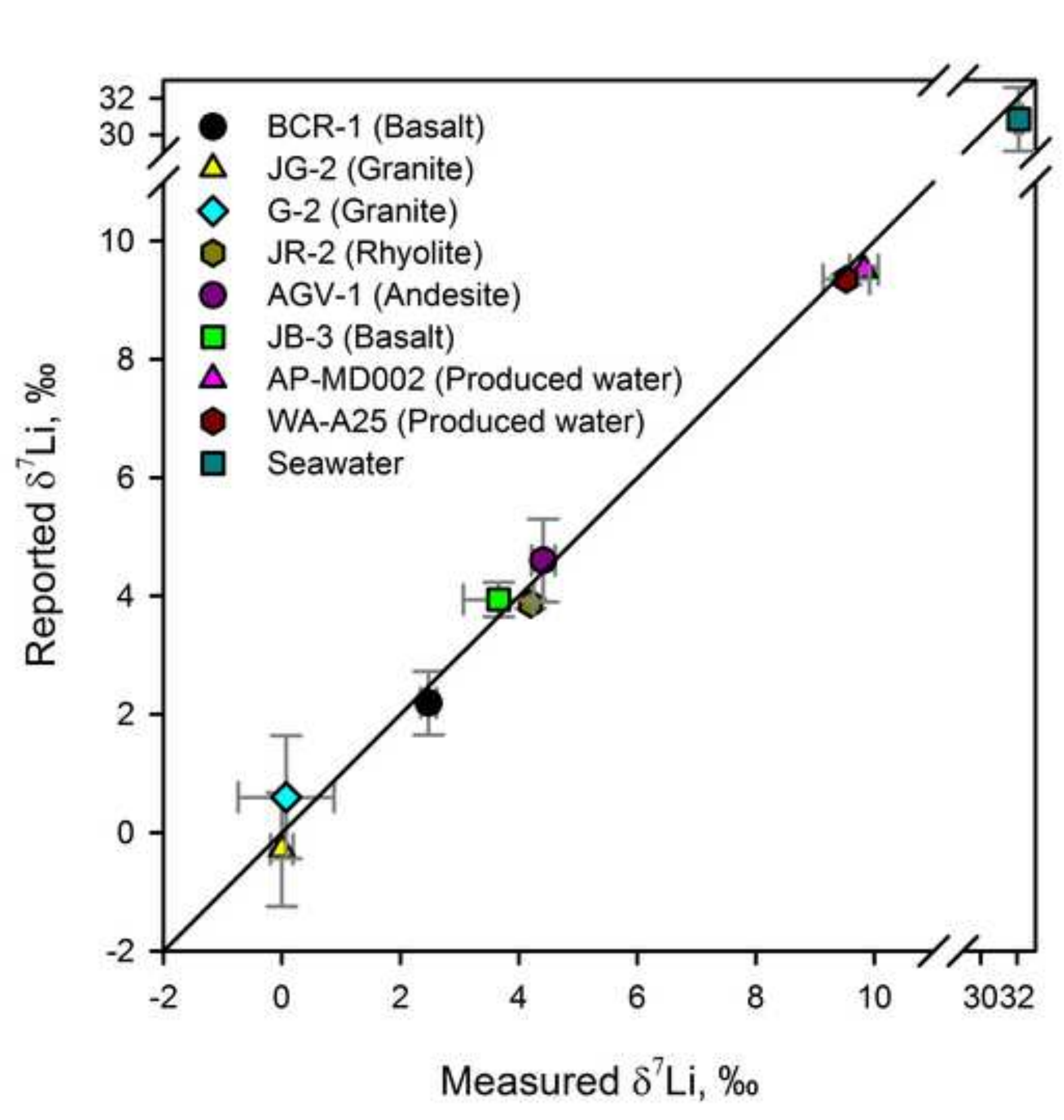

Figure 3
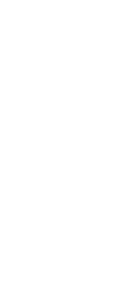

\author{
Measured $8 \mathrm{Li}, \%$
}

Figre 3 

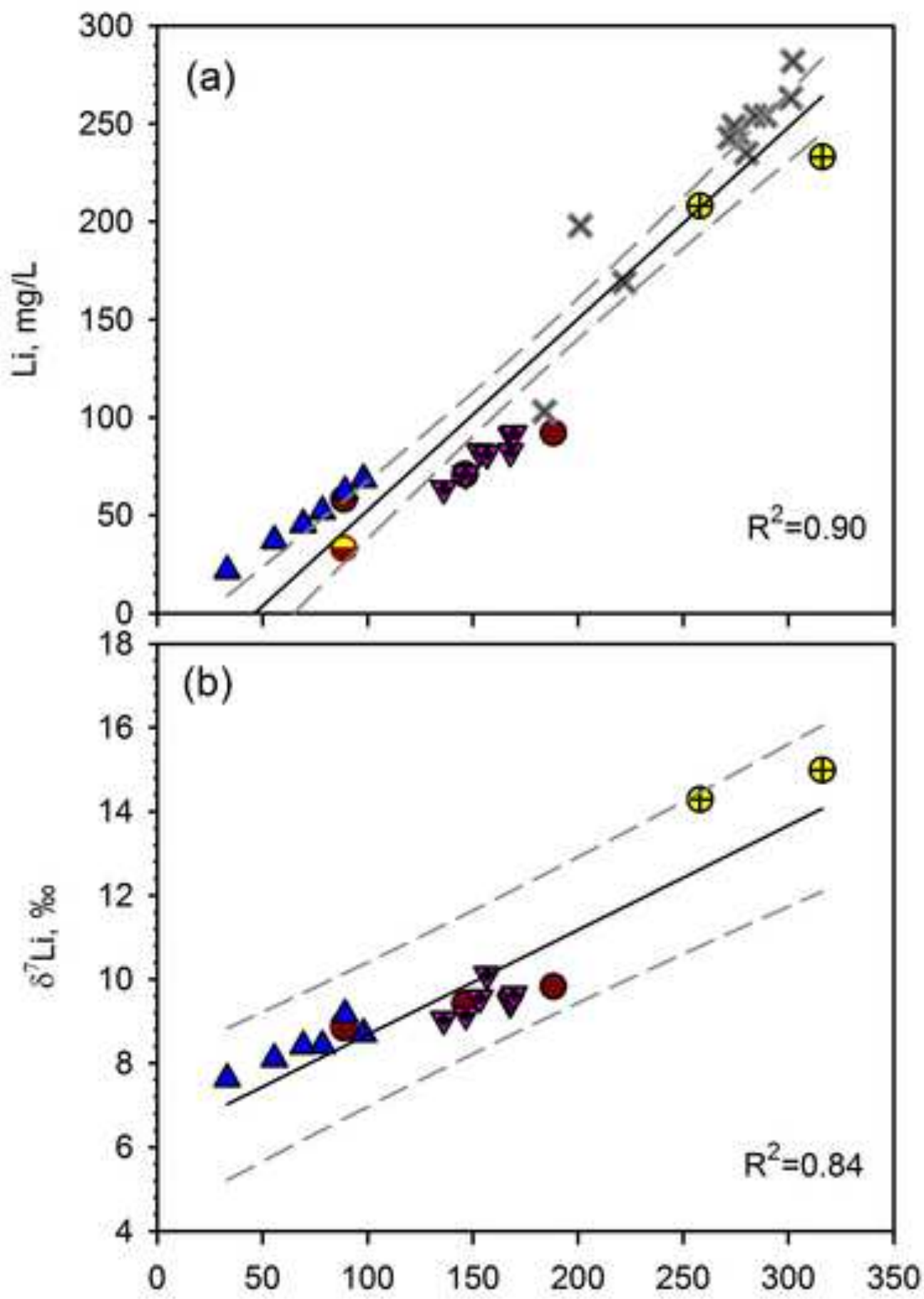

Southwestern PA

TDS, $g / L$

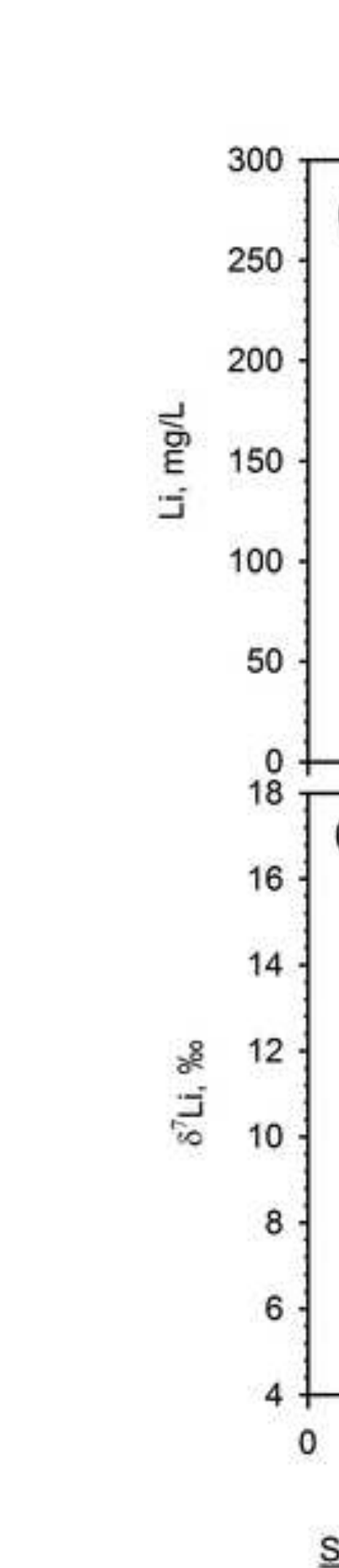

A Well 7

7 Well 8

- Well 9

- Frac water of Well 9

Northcentral PA

$$
\begin{array}{ll}
\oplus & \text { SA14 and CO12 } \\
\times & \text { Multiple wells (Rowan et al., 2015) }
\end{array}
$$



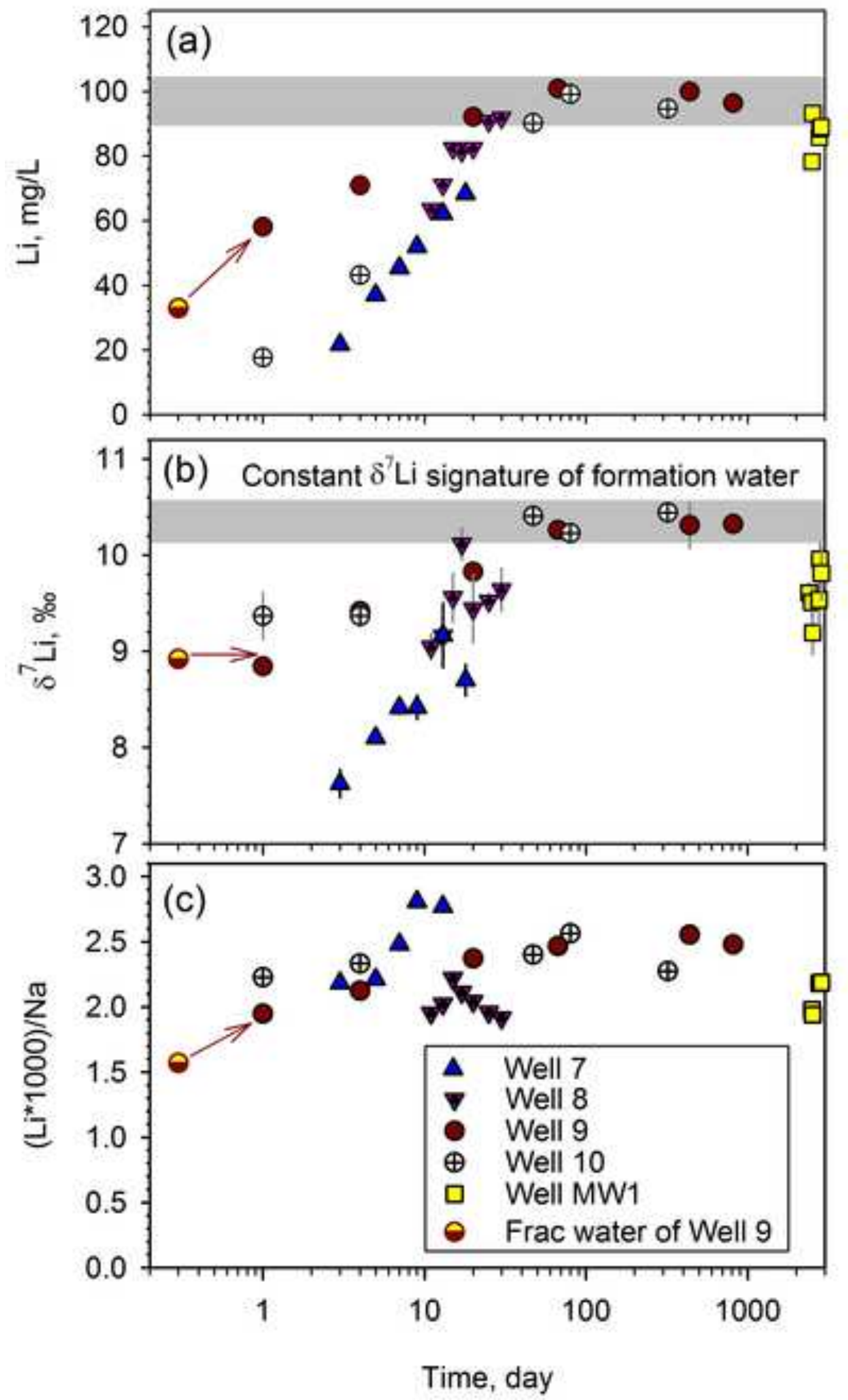


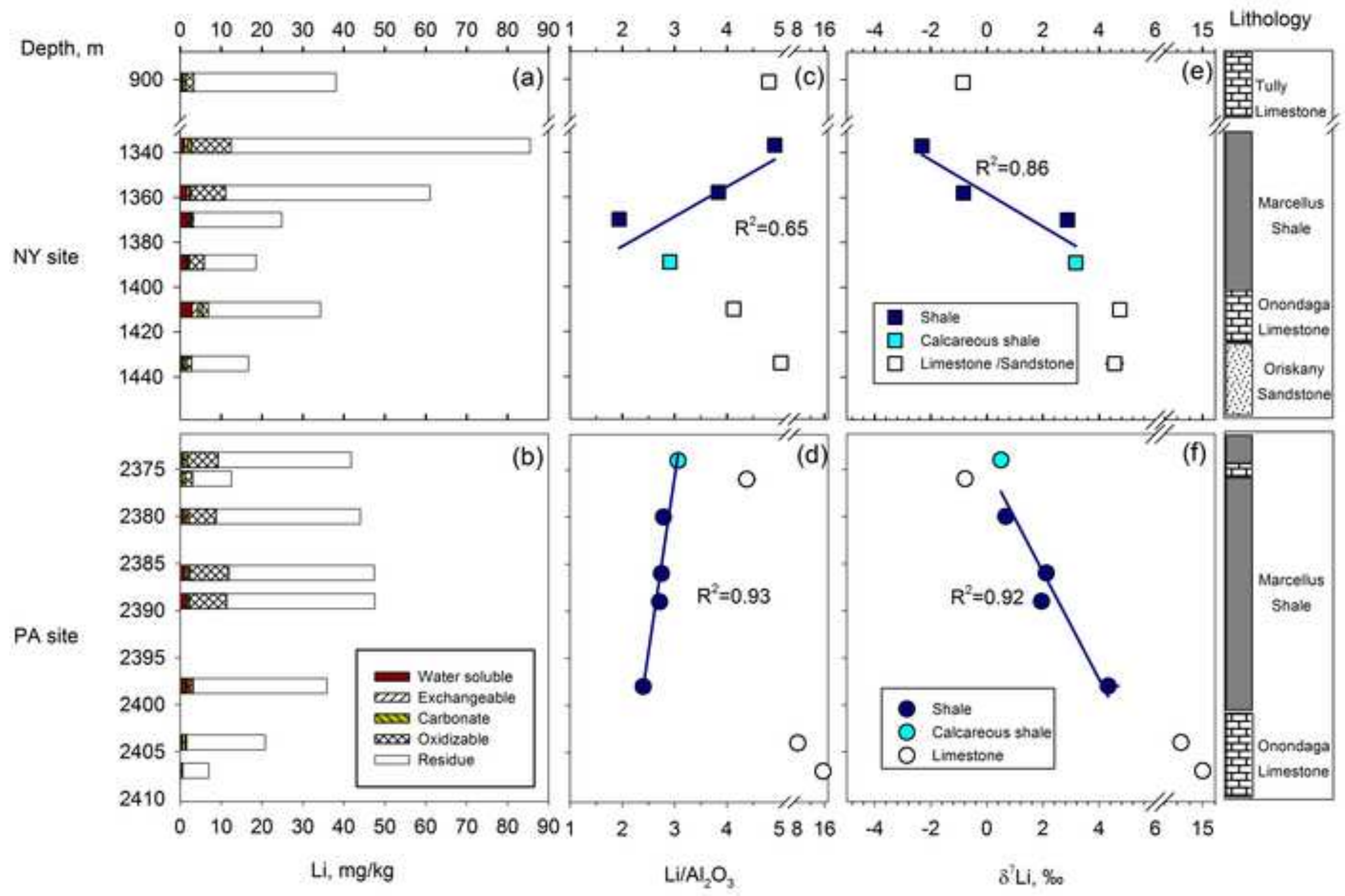



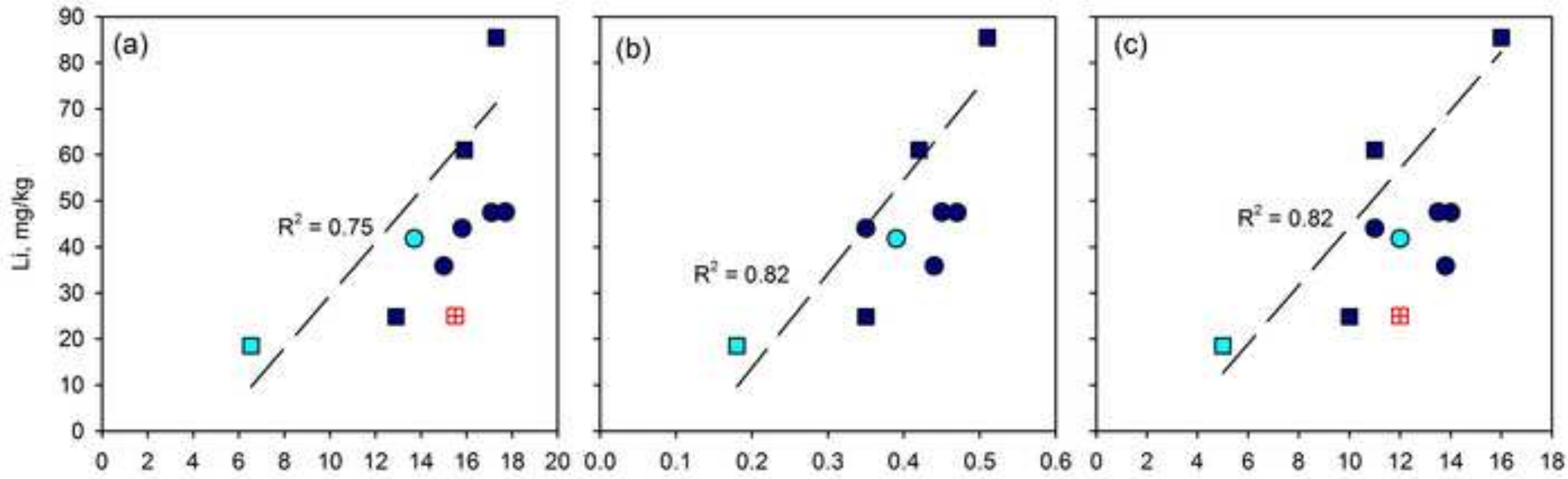

$\mathrm{Al}_{2} \mathrm{O}_{3}, \%$

$\mathrm{TiO}_{2}, \%$

$\mathrm{Nb}, \mathrm{mg} / \mathrm{kg}$
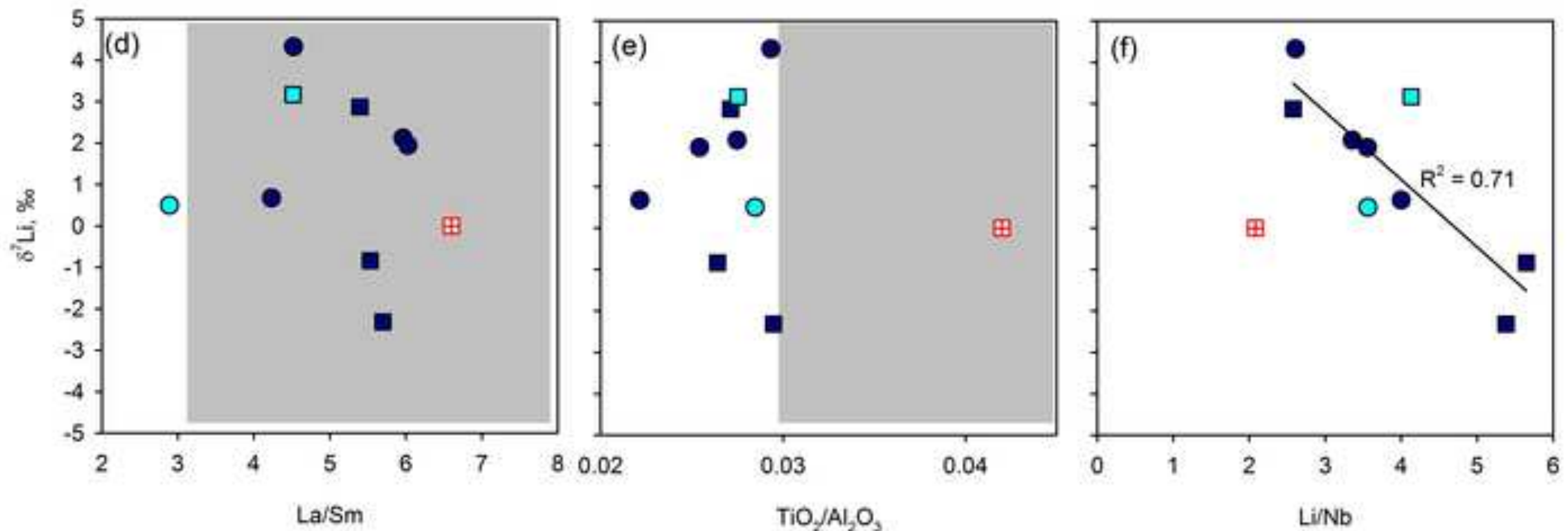

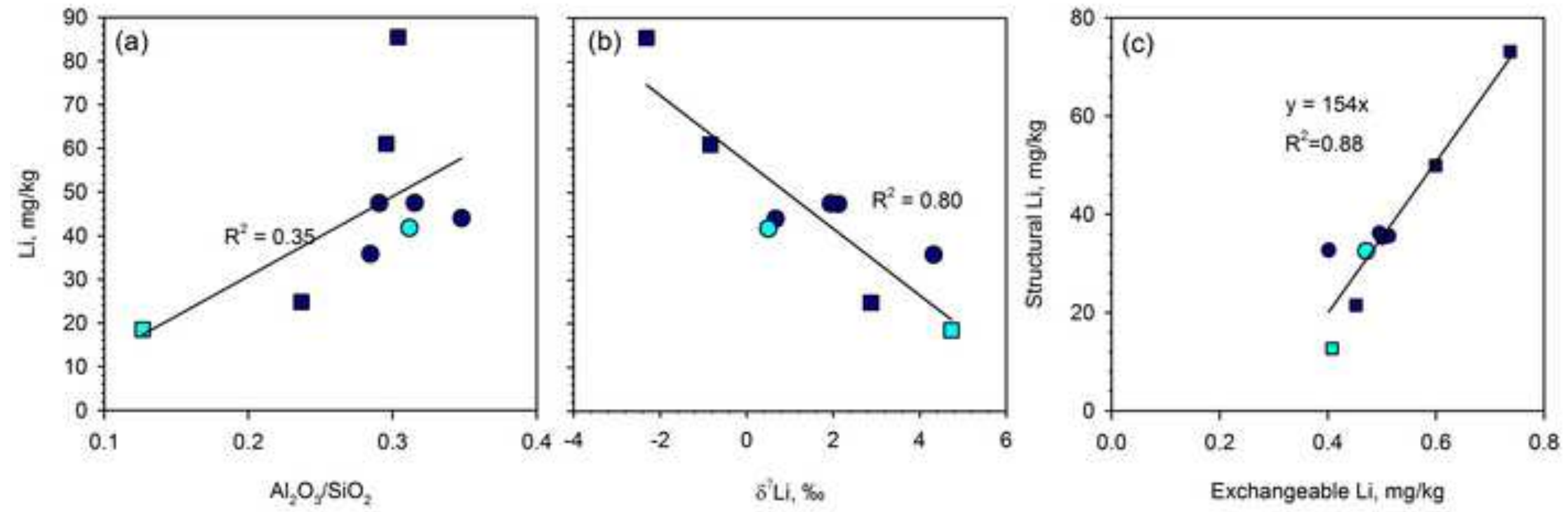
Figure 9

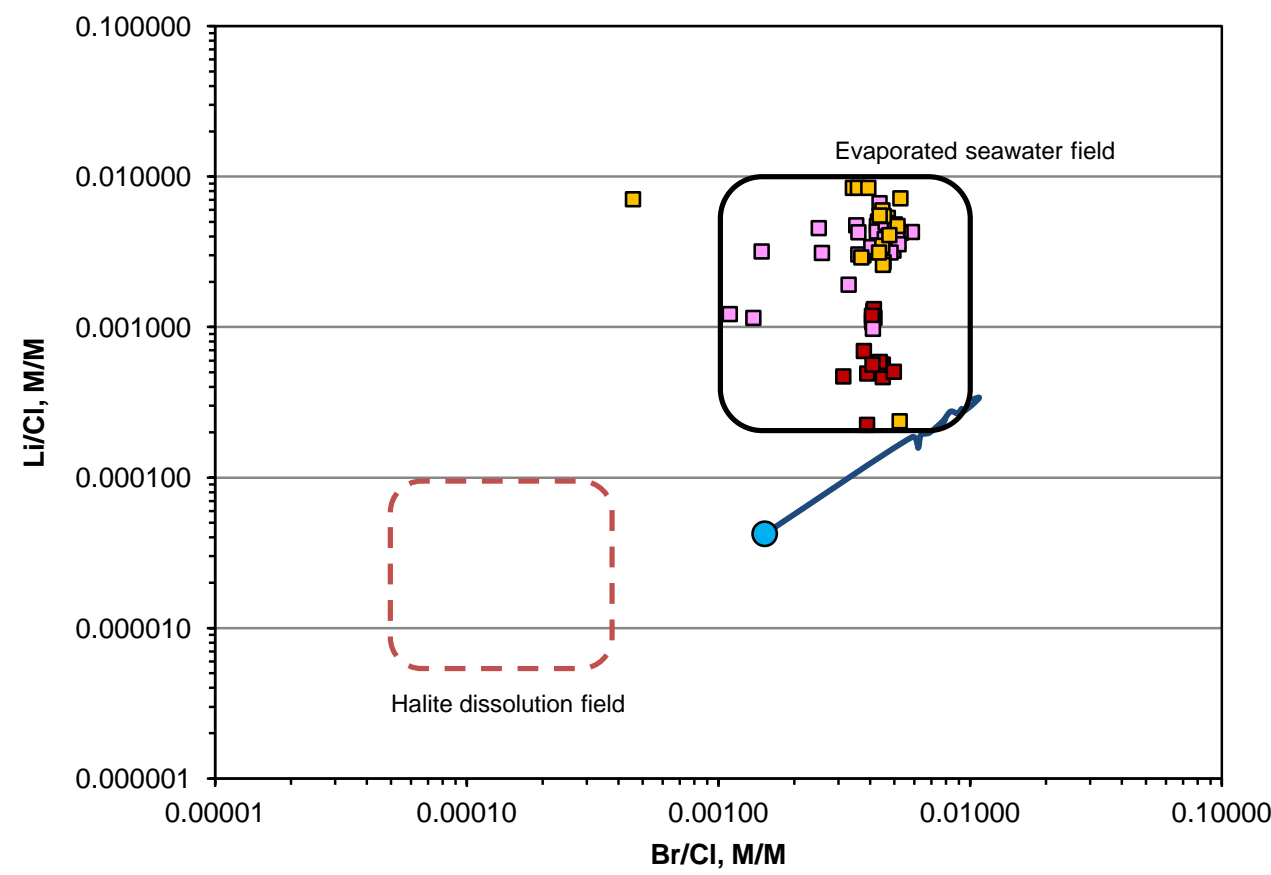

- Upper Devonian - Formation water

․ Silurian - Formation water

․ Middle Devonian - Formation water

- Seawater 


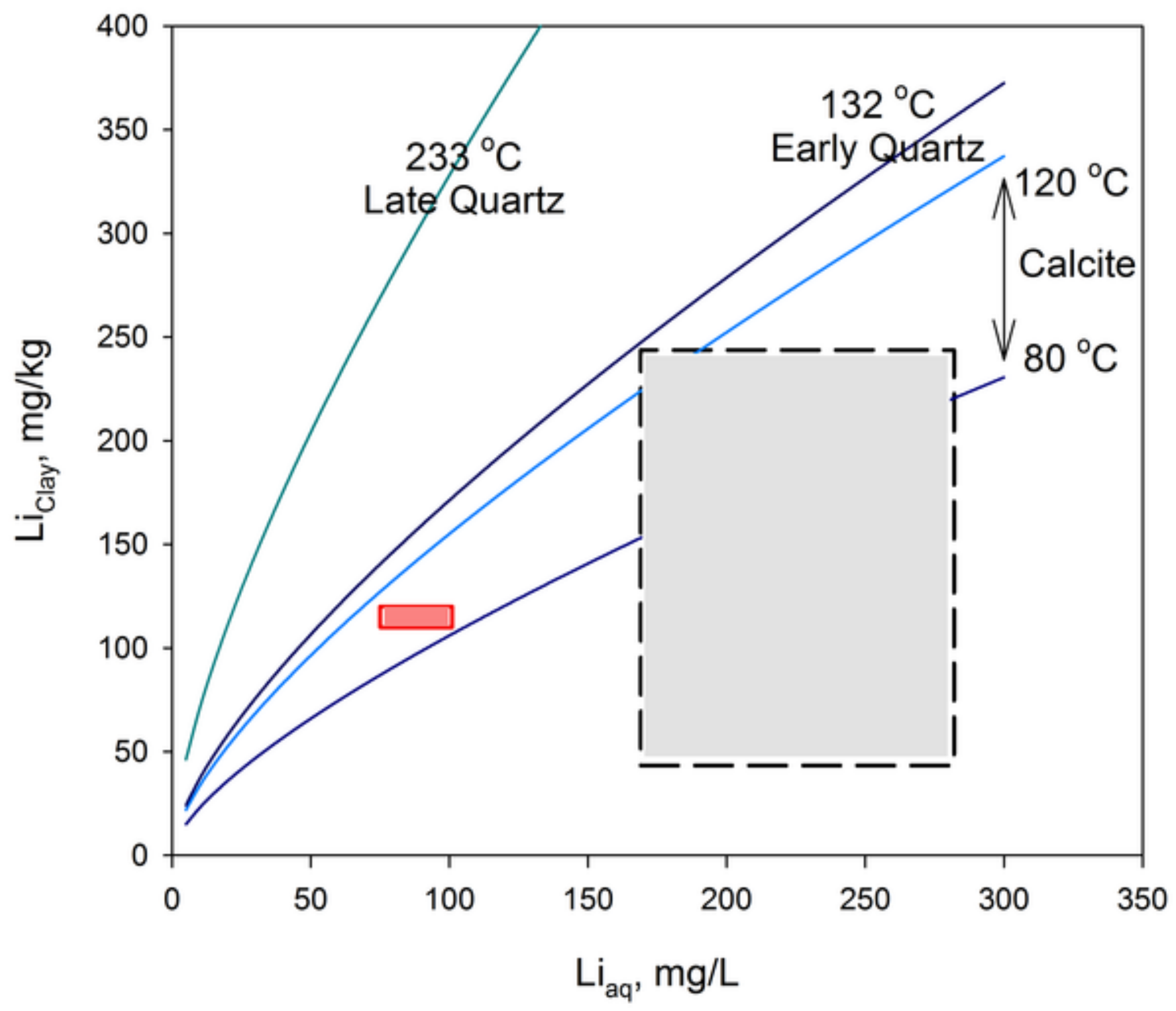



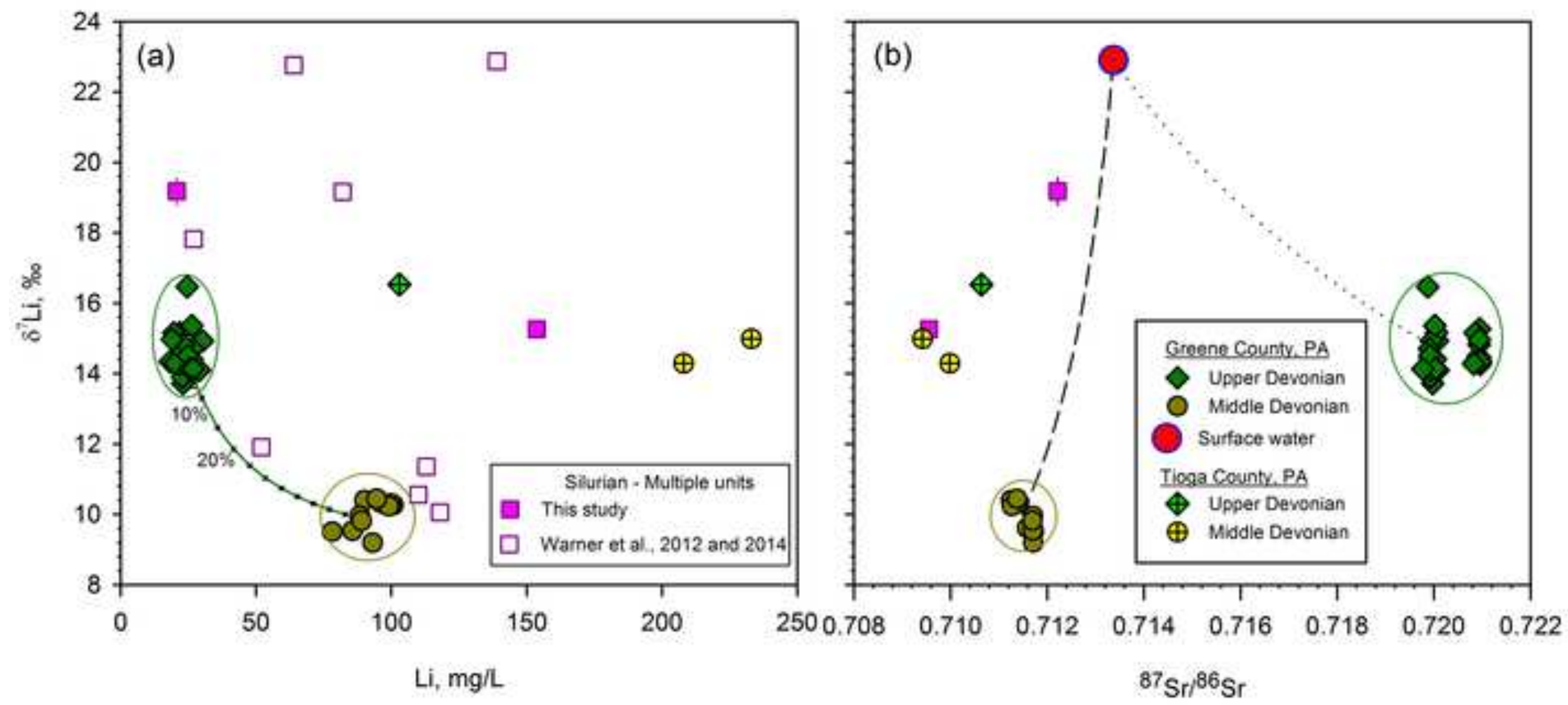
Marcellus Shale (Middle Devonian)

Onondaga Limestone
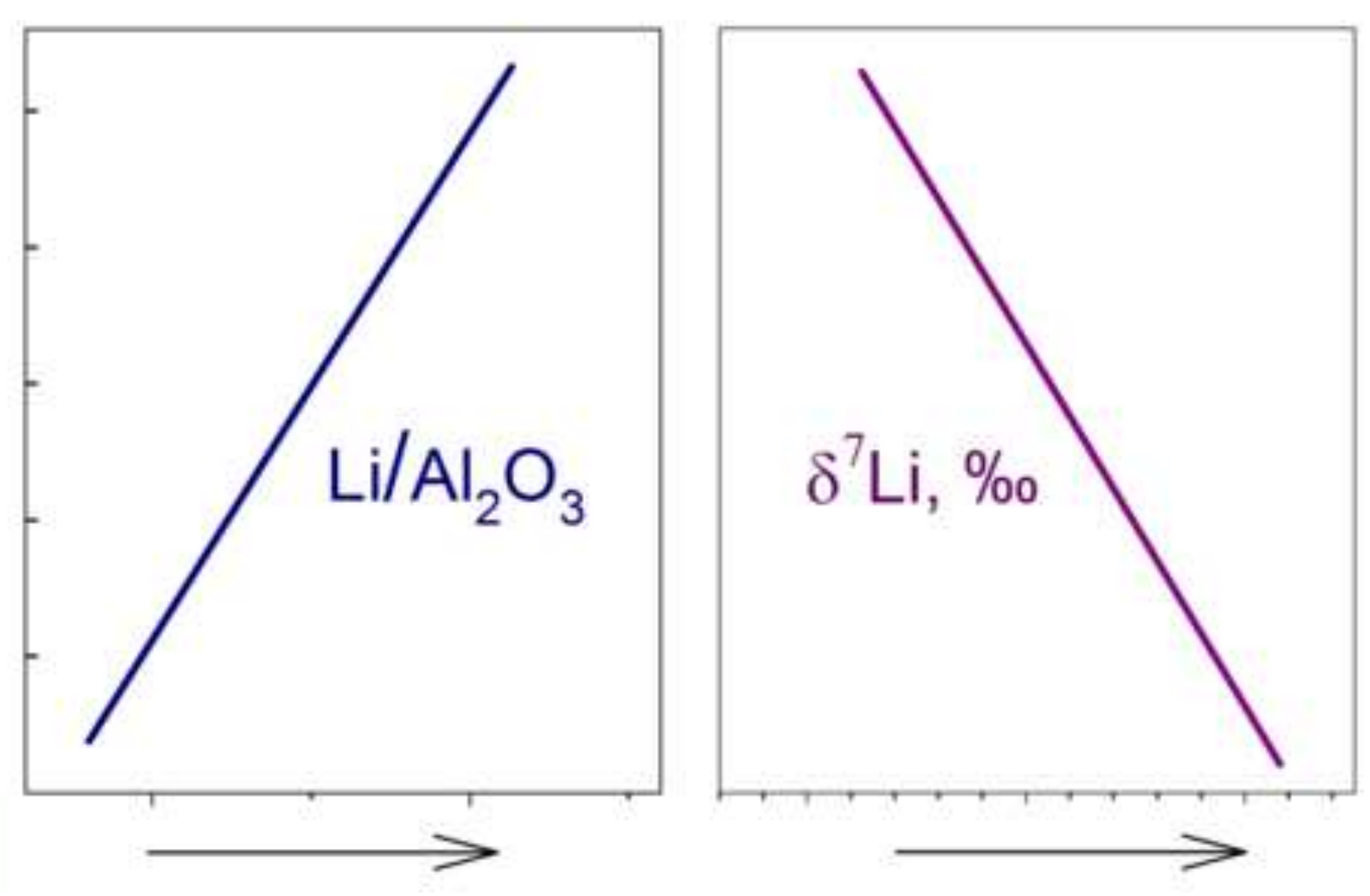